\title{
Geological Characteristics of Mud Volcanoes and Diapirs in the Northern Continental Margin of the South China Sea: Implications for the Mechanisms Controlling the Genesis of Fluid Leakage Structures
}

\author{
Siling Zhong $\mathbb{D}^{1,2}$ Jinfeng Zhang $\mathbb{D}^{1,2}$ Junsheng Luo $\mathbb{D}^{1},{ }^{1}$ Yajuan Yuan $\mathbb{D},{ }^{3}$ and Pibo Su $\mathbb{D}^{4}$ \\ ${ }^{1}$ School of Marine Sciences, Sun Yat-sen University/Southern Marine Science and Engineering Guangdong Laboratory (Zhuhai), \\ Zhuhai 519000, China \\ ${ }^{2}$ Southern Marine Science and Engineering Guangdong Laboratory (Zhanjiang), Zhanjiang 524000, China \\ ${ }^{3}$ School of Geography, South China Normal University, Guangzhou 510631, China \\ ${ }^{4}$ MLR Key Laboratory of Marine Mineral Resources, Guangzhou Marine Geological Survey, Ministry of Natural Resources, \\ Guangzhou 510075, China
}

Correspondence should be addressed to Yajuan Yuan; yuanyajuan@m.scnu.edu.cn and Pibo Su; supibo@qq.com

Received 17 January 2021; Accepted 10 May 2021; Published 27 May 2021

Academic Editor: Priyank Jaiswal

Copyright ( 2021 Siling Zhong et al. This is an open access article distributed under the Creative Commons Attribution License, which permits unrestricted use, distribution, and reproduction in any medium, provided the original work is properly cited.

\begin{abstract}
Mud volcanoes and diapirs are geological structures formed due to arch piercing or diapiric intrusion of ductile sedimentary materials into the overlying strata along high permeability channels. A detailed study on the processes controlling the formation of mud volcanoes and diapirs in the northern continental margin of the South China Sea is of vital importance to the exploration of economically viable oil and gas reservoirs and can be helpful to the exploration of natural gas hydrate in a sedimentary basin. The fluid seepage structures that occur in the Mesozoic and Cenozoic sedimentary basins of the northern South China Sea show significant differences in their morphological and tectono-structural characteristics. We used highresolution seismic profiles and instantaneous frequency profiles to understand the mechanisms that are critical with respect to the differential development of the investigated piercement structures. Differences in stress field do not directly lead to the difference in the scale of mud volcanoes or diapirs. Fractures may play an important role in the formation of mud volcanoes and diapirs. The thickness of the sediment was found to have a strong impact on the formation of fluid leakage structures that thicker sediments are more conducive to the development of mud diapirs and the thinner one is more likely to form mud volcanoes.
\end{abstract}

\section{Introduction and Rationale of the Study}

Mud volcanoes and diapirs are piercement structures formed due to subterranean high pressure $(P)$ imposed on ductile material in deep basins hosting relatively thick sedimentary sequences. These structures are produced by arching or diapiric intrusion into the overlying strata along highpermeability channels, such as zones of mechanical weakness (e.g., fractures and faults [1-4]). Mud volcanoes are formed when a mud slurry exudate is forced upwards, piercing the surface or the seafloor. Conversely, when the oozing, high- plasticity material cannot pierce to the surface or the seafloor, mud diapirs are formed [2].

Piercement structures are widely distributed all over the world. Mud volcanoes have been reported from more than 40 continental regions and 20 seas around the world [1, 2, 5-9]. Among them, the Mediterranean Ridge, the Niger Delta, Azerbaijan, and the northern continental margin of the South China Sea host a huge number of mud volcanoes or mud diapirs [10-13]. Mud volcanoes and diapirs commonly occur in accretionary wedge regions subjected to compressive stress such as the Mediterranean Ridge [14-16] and 
the Island of Barbados [17]. Less frequently, they appear in extensional provinces such as the Black Sea $[18,19]$ and the Southeastern Tyrrhenian Sea [20]. Furthermore, some mud volcanoes and diapirs are both associated with stretching and extrusion environments such as the Western Alboran Sea $[21,22]$.

Mud volcanoes and diapirs are structures of great geological significance. They are closely linked to the tectonosedimentary evolution of basins and may play an important role in hydrocarbon migration and accumulation [1, 2325]. Submarine mud volcanoes and diapirs can be important markers of deep-water petroleum and shallow gas hydrate deposits [26-30]. In addition, mud volcanic activity can be used as an important indicator of early oil and gas evaluation in sedimentary basins [31-33]. The large amount of methane $\left(\mathrm{CH}_{4}\right)$ emitted from mud volcanoes accelerates the greenhouse effect, contributing to climate changes on a global scale $[1,34,35]$. Lastly, diapiric and volcanic activities underneath geological basins are prominent indicators of neotectonic movements and may lead to fatal geological disasters [36, 37].

Previous studies on mud volcanoes and diapirs focused on various aspects, including their geological structure $[2,5$, $8,38,39]$ and geochemical [8, 34, 40, 41] and geophysical $[4,36,42,43]$ signatures. Some of these researches tried to discuss the formation mechanism of mud volcanoes or diapirs (e.g., $[9,13])$ and the relationships between the evolution of such piercement structures and hydrocarbon or gas hydrate accumulation $[2,44]$.

Investigating the genetic mechanisms of mud volcanoes and diapirs in the northern part of the South China Sea is of great significance for understanding the migration and accumulation processes of petroleum and gas. According to the analysis of geology, geophysics, geochemistry, biology, and thermodynamics of the South China Sea (e.g., [12, 43, 45-48]), hundreds of mud volcanoes and diapirs have been reported in the northern continental marginal basins of the South China Sea (Figure 1), i.e., the Yinggehai, Qiongdongnan, Pearl River Mouth, and Southwest Taiwan Basins. Previous studies mainly describe the types, morphology, development characteristics, and distribution of fluid leakage structures in one of these basins or inferred the source of fluid by combining seismic profile and geochemical analysis (e.g., [49]). These cannot sufficiently explain the differences in the formation processes of the mud volcanoes and diapirs developing in the northern South China Sea. At present, the mechanisms that control the formation of mud volcanoes and diapirs around the world remain unclear or debatable (e.g., [50-52]). Therefore, it is essential to thoroughly analyze the characteristics of the overlying Cenozoic sediments, overpressure, and the tectonic stress background of basins to better understand the mechanisms that control the evolution of mud volcanoes and diapirs in the northern South China Sea. And it plays an important part in the exploration of oil and gas reservoirs and can be helpful to the exploration of natural gas hydrate in a sedimentary basin.

In this paper, the development characteristics of mud volcanoes and mud diapirs in the northern margin of the South China Sea were summarized by combining literature research and seismic profile interpretation. We analyze the differences in the type and thickness of the Cenozoic sediments, tectonic stress, and lithostatic pressure $(P)$ between the Yinggehai, Qiongdongnan, Pearl River Mouth, and Southwest Taiwan Basins and discuss influences of the overpressure, the thickness of sediments, and the stress on the formation process of piercement structures.

\section{Geological Background}

The northern continental margin of the South China Sea is located on the southeastern margin of the Eurasian megaplate. The geodynamic environment of this area is very complex due to the competitive influence of the Eurasian, IndianAustralian, and Pacific-Philippines Sea lithospheric plates and the opening of the South China Sea, among other factors [53-56]. The South China Sea has experienced multiple tectonic events, and its Cenozoic evolution is marked by an early Paleogene episode of continental fault depression and a late Neogene and Quaternary event of subsidence of marine facies. Furthermore, the northern continental marginal basin of the South China Sea has undergone rapid subsidence and sedimentation, giving rise to a thick Cenozoic sedimentary sequence characterized by high (fluid and lithostatic) pressure $(P)$ and temperature $(T)$ conditions in its lowermost parts.

There are many Mesozoic and Cenozoic sedimentary basins in the northern continental margin of the South China Sea including the Yinggehai, Beibu Gulf, Qiongdongnan, Pearl River Mouth, and Southwest Taiwan Basins [57]. The Yinggehai Basin is controlled by a strike-slip fault zone in the western margin of the South China Sea. The Qiongdongnan and Pearl River Mouth Basins are characterized by extensional rifting and uplift structures that were formed during the rift period. The Southwest Taiwan Basin, located at the edge of the South China Sea subduction and convergence zone, is controlled by lithospheric slab subduction and compressional faulting [58-61]. In the late Cenozoic ( $5 \mathrm{Ma}$ years ago), the continental marginal structure of the northern South China Sea was relatively stable, but the eastern margin of the South China Sea was strongly affected by the westward pushing Philippine plate. And the process of the strike-slip movement of the Red River Fault Zone affected the activity of the fault zone alongside the western margin of the study area [62].

The thickness of the sedimentary sequences over the northern continental margin of the South China Sea varies significantly (Figure 2). The thickness of the Cenozoic sediment is $\sim 17 \mathrm{~km}$ in the Yinggehai Basin, whereas it may exceed $10 \mathrm{~km}$ in the deep-water area of the southern Qiongdongnan Basin. The Baiyun sag of the Pearl River Mouth Basin has a sedimentary sequence more than $10 \mathrm{~km}$ thick [49]. The thickness of the Cenozoic sedimentary rocks of the Southwest Taiwan Basin is $5 \mathrm{~km}$ on average and $\sim 8 \mathrm{~km}$ at its maximum. The above-mentioned basins all have obvious formation overpressure, except the Pearl River Mouth Basin. Among them, the pressure coefficient in the central depression area of the Yinggehai Basin is basically greater than 2.0 and the pressure coefficient is 1.5 2.2 approximately in the center of the Qiongdongnan Basin and the depression 


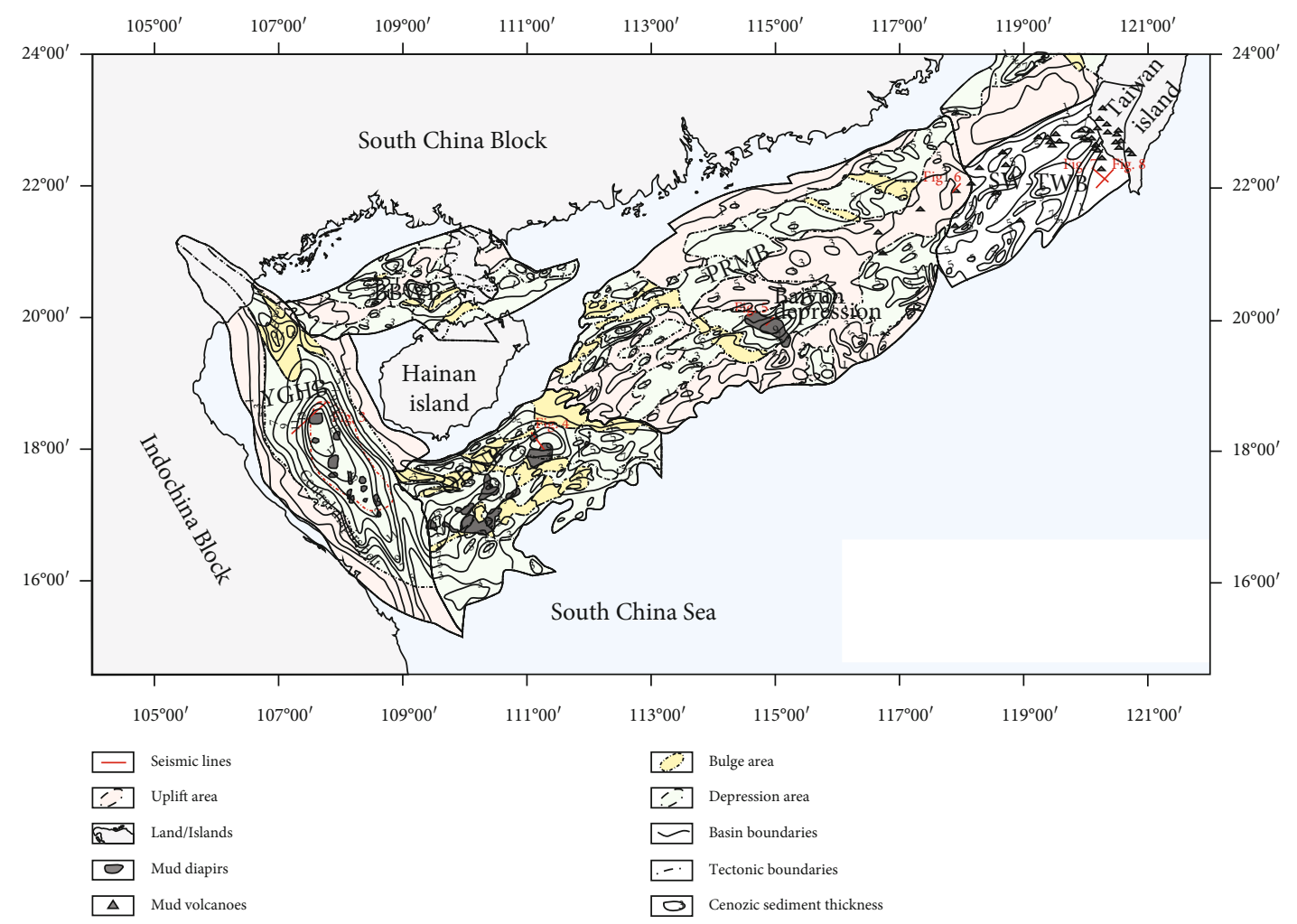

FIGURE 1: Distribution of mud volcanoes and mud diapirs in the northern margin of the South China Sea. Grey parts indicate mud diapirs of Yinggehai Basin (YGHB), Qiongdongnan Basin (QDNB), and Pearl River Mouth Basin (PRMB); grey triangles indicate mud volcanoes in the Dongsha Islands and Southwest Taiwan Basin (SW-TWB). Red lines indicate the location of seismic lines. Different colors (pink, yellow, and green) represent uplift, bulge, and depression areas, respectively (modified from $[13,49]$ ). Black solid lines with numbers represent Cenozoic sediment thickness (modified from "Map of Cenozoic Sediment Thickness 1:2 000 000," Atlas of geology and geophysics of the South China Sea, compiled by Guangzhou Marine Geological Survey); mud volcanoes and mud diapirs are found in areas of thick sediment.

center of this basin. These differences strongly affected the distribution and evolution characteristics of mud volcanoes and diapirs in each sediment basin of the South China Sea.

\section{Research Approach}

Guangzhou Marine Geological Survey (GMGS) and China National Offshore Oil Corporation (CNOOC) conducted extensive and detailed geophysical studies in the northern continental margin of the South China Sea. A large number of mud volcanoes and diapirs were recognized in the Yinggehai, Qiongdongnan, and Pearl River Mouth Basins on 2D and 3D seismic profiles and instantaneous frequency profiles (e.g., 25, 39, 43, 47-49). High-resolution multichannel 2D and 3D seismic datum we used below belong to the Guangzhou Marine Geological Survey (GMGS). In the course of geological and geophysical investigations, the seismic streamer was a Seal 24-bit digital cable produced by the Sercel Company in French. The cable was immersed in $8 \mathrm{~m}$, and the air gun is immersed in $5 \mathrm{~m}$. The channel number of a seismic streamer was 240, and the number of coverage is 60 times. The interval between receivers, shot interval, and the offset were $12.5,25$, and $175 \mathrm{~m}$, respectively. The sampling rate was $1 \mathrm{~ms}$, and the record length was $6 \mathrm{~s}$. The frequency range of the original seismic data is 6 to $160 \mathrm{~Hz}$, and the main frequency was about $75 \mathrm{~Hz}$. GMGS processing datum is by the
GeoCluster 2.1 (CGG) processing system of French Geophysical Company. In addition, the instantaneous frequency profile can help to detect high attenuation areas such as free gas zones and gas chimneys [47]. Our datum and preexisting information on the type of fluid seepage structures in the aforementioned basins and the Southwest Taiwan Basin are used herein to discuss the distribution, genetic mechanism, and development characteristics of mud volcanoes and diapirs.

\section{Results}

Fluid seepage structures in mud volcanoes and diapirs frequently occur in Yinggehai, Qiongdongnan, Pearl River Mouth, and Southwest Taiwan Basins. Their distribution and evolution characteristics differ much among basins (Table 1). For instance, mud diapirs were recognized in the Yinggehai, Qiongdongnan, Pearl River Mouth, and Southwest Taiwan Basins. And most mud volcanoes occur in the Pearl River Mouth Basin, Southwest Taiwan Basin, and the Taiwan land [13, 39, 49, 63].

4.1. Characteristics of Mud Diapirs in the Yinggehai Basin. Mud diapirs in the Yinggehai Basin are the most typical of those found in the northern continental marginal basin of the South China Sea. Most of them are located in the central 

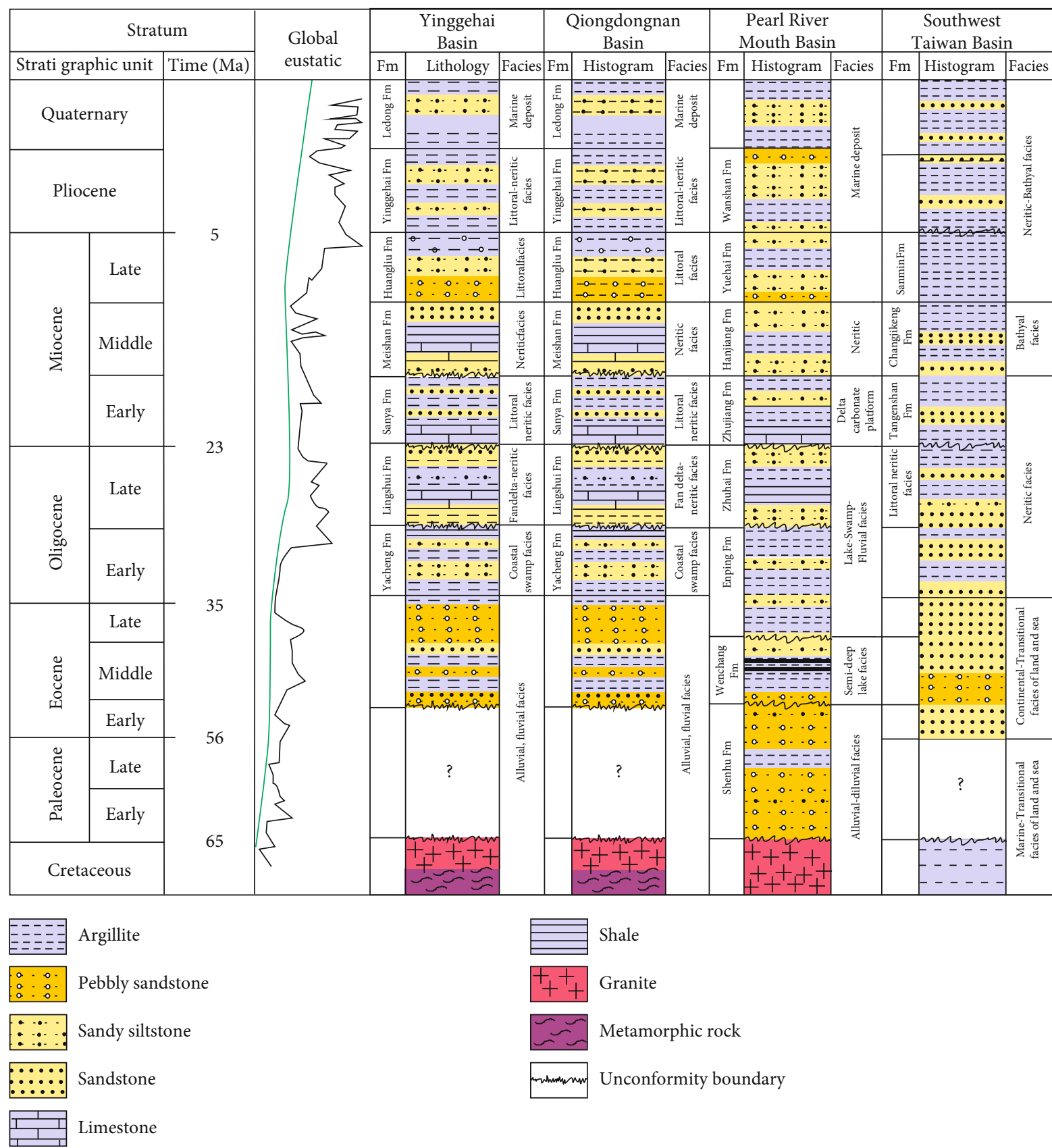

FIGURE 2: Stratigraphic integrative column map of basins in the northern margin of the South China Sea (modified from [57]).

depression of the basin in five rows parallel to the long axis of the basin in the central uplift belt [25]. The largest covers an area of more than $700 \mathrm{~km}^{2}$ and most others tens to hundreds of $\mathrm{km}^{2}[25,64]$. The seismic profile shows that there are blank and cluttered anomalous seismic emission characteristics that are significantly different from the surrounding rock inside the mud diapir (Figure 3). Mud diapirs are developed in the Miocene stratum, piercing the T30 interface vertically and reaching the upper Yinggehai Formation. Mud diapir caused the "pull up" of the surrounding rock on both sides of it, and an upward arching phenomenon occurs on the top of the diapir.
4.2. Characteristics of Mud Diapirs in the Qiongdongnan Basin. Mud diapirs in the Qiongdongnan Basin are predominantly concentrated in the sedimentary center of the basin depression and in the deeper, thicker deposits in the transition zone of the sags and bulges of the basin (Figure 1). Diapirs are typically distributed in a NE direction at the deepwater area in the south and relatively concentrated in the Songnan low bulge and Lingnan low bulge areas [65]. Mud diapirs appear as vertically oriented or chimney-like structures on the seismic profiles, have some seismic anomalies such as clutter and blank inside them, and vary in sizes (Figure 4(a)). These blank or cluttered reflection signals 
TABLE 1: Characteristics of mud volcanoes and mud diapirs in the northern South China Sea [25, 39, 43, 65-68].

\begin{tabular}{|c|c|c|c|}
\hline & Scales & Distribution & Characteristics \\
\hline $\begin{array}{l}\text { Yinggehai } \\
\text { Basin }\end{array}$ & $\begin{array}{l}\text { Mud diapirs tens to hundreds of square } \\
\text { kilometers, up to } 700 \mathrm{~km}^{2} \text {. }\end{array}$ & $\begin{array}{l}\text { Primarily distribute in the central } \\
\text { depression of the basin. }\end{array}$ & $\begin{array}{l}\text { Mud diapir belts are arranged in a row } \\
\text { of } 5 \text { rows of geese along the long axis of } \\
\text { the basin. }\end{array}$ \\
\hline $\begin{array}{l}\text { Qiongdongnan } \\
\text { Basin }\end{array}$ & Mud diapirs. & $\begin{array}{l}\text { Predominantly concentrate in the } \\
\text { sedimentary center of the basin } \\
\text { depression and in the deeper, thicker } \\
\text { deposits in the transition zone of the } \\
\text { sags and bulges. }\end{array}$ & $\begin{array}{l}\text { Mud diapirs varying in scale, structural } \\
\text { style, and piercing layers. Mud diapirs } \\
\text { are randomly distributed but } \\
\text { occasionally occur in groups. }\end{array}$ \\
\hline \multirow[t]{2}{*}{$\begin{array}{l}\text { Pearl River } \\
\text { Mouth Basin }\end{array}$} & \multirow{2}{*}{$\begin{array}{l}\text { Mud diapirs in Baiyun sag reach up to } \\
8 \mathrm{~km} \text {, and the largest one covers an area } \\
\text { of } 1000 \mathrm{~km}^{2} . \text { Mud volcanoes in } \\
\text { Dongsha islands have widths and } \\
\text { heights of } 0.5-2.0 \mathrm{~km} \text { and } 50-200 \mathrm{~m} \text {. }\end{array}$} & $\begin{array}{l}\text { Mud diapirs of Baiyun sag extend } \\
\text { approximately NWW and are } \\
\text { predominantly distributed in the } \\
\text { southwestern part of the center of } \\
\text { Baiyun sag. }\end{array}$ & $\begin{array}{l}\text { Relatively concentrated distribution, } \\
\text { generally consistent with the NWW } \\
\text { fault system in the late Miocene, and } \\
\text { the piercing layers are different. }\end{array}$ \\
\hline & & $\begin{array}{l}\text { Many active mud volcanic belts were } \\
\text { founded in the southwestern area of the } \\
\text { Dongsha Islands. }\end{array}$ & $\begin{array}{l}\text { Mud volcanoes have characteristics of } \\
\text { structural extrusion and are distributed } \\
\text { in a SWW-NEE direction. }\end{array}$ \\
\hline $\begin{array}{l}\text { Southwest } \\
\text { Taiwan Basin }\end{array}$ & $\begin{array}{l}94 \text { mud volcanoes ranging in height } \\
\text { from } 65 \text { to } 345 \mathrm{~m} \text {, with a pedestal } \\
\text { diameter of approximately } \\
680 \sim 4100 \mathrm{~m} \text {. Mud ridges ranging from } \\
3.9 \text { to } 56.5 \mathrm{~km} \text { in length and } 1.6 \text { to } \\
8.3 \mathrm{~km} \text { in width. }\end{array}$ & $\begin{array}{l}\text { Mud volcanoes and mud diapirs are } \\
\text { primarily distributed in the deep waters } \\
\text { of the southern depression of the basin. }\end{array}$ & $\begin{array}{l}\text { Mainly distributed in the structural } \\
\text { fault zone, mud volcanoes are mostly } \\
\text { distributed on mud diapirs. }\end{array}$ \\
\hline
\end{tabular}

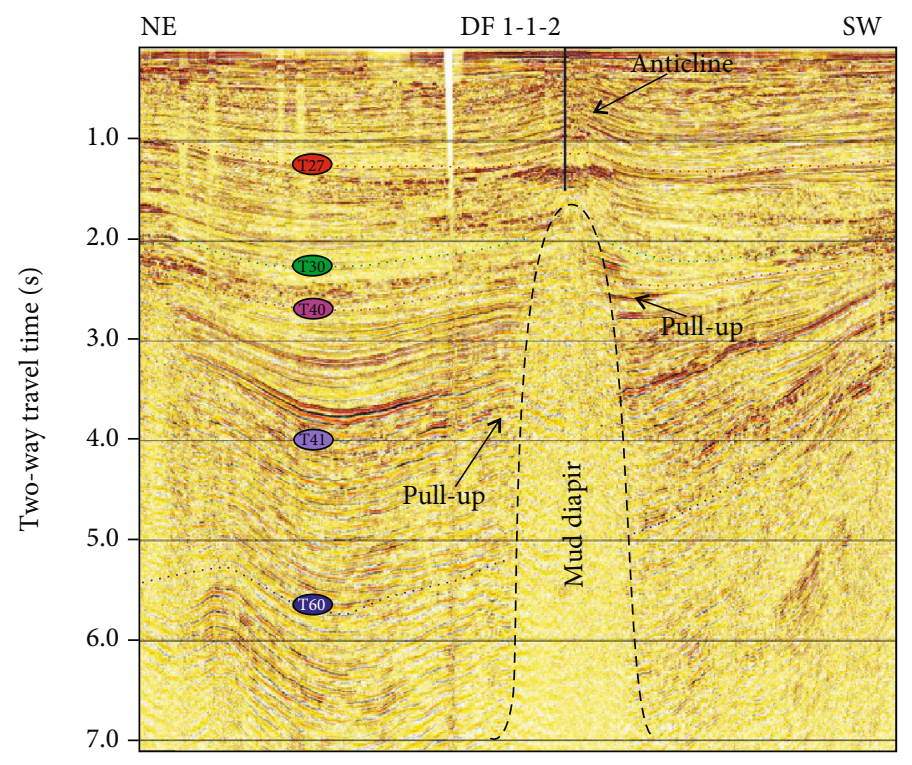

Figure 3: Seismic profile over the Yinggehai Basin. There are blank and cluttered anomalous seismic emission characteristics that are significantly different from the surrounding rocks. The mud diapir is developed in the Miocene stratum, piercing the T30 interface in a vertical column and reaching the upper stratigraphic layer of the Yinggehai Formation stratum. Above the top of the diapir, there is a phenomenon of upward arching of the stratum. Uplift of the mud diapirs caused the "pull up" of the surrounding rock on both sides.

exhibit lower instantaneous frequency values from deep to shallow on the instantaneous frequency profile, which is significantly different from the higher instantaneous frequency values of the surrounding rocks (Figure 4(b)). Owing to the upward migration of gas, some mud diapirs may give "pulldown" internal seismic reflection signatures (Figure 4(a)). The overlying strata of the mud diapirs are plastically arched owing to the puncturing effect of diapirism, resulting in the formation and propagation of high-angle brittle faults and radially arranged fractures.

4.3. Characteristics of Mud Volcanoes and Diapirs in the Pearl River Mouth Basin. A large number of mud diapirs have been recorded in the Baiyun sag of the Pearl River Mouth Basin. The maximum intrusion height of mud diapirs in this area reaches $8 \mathrm{~km}$, and the largest one covers a total area of 


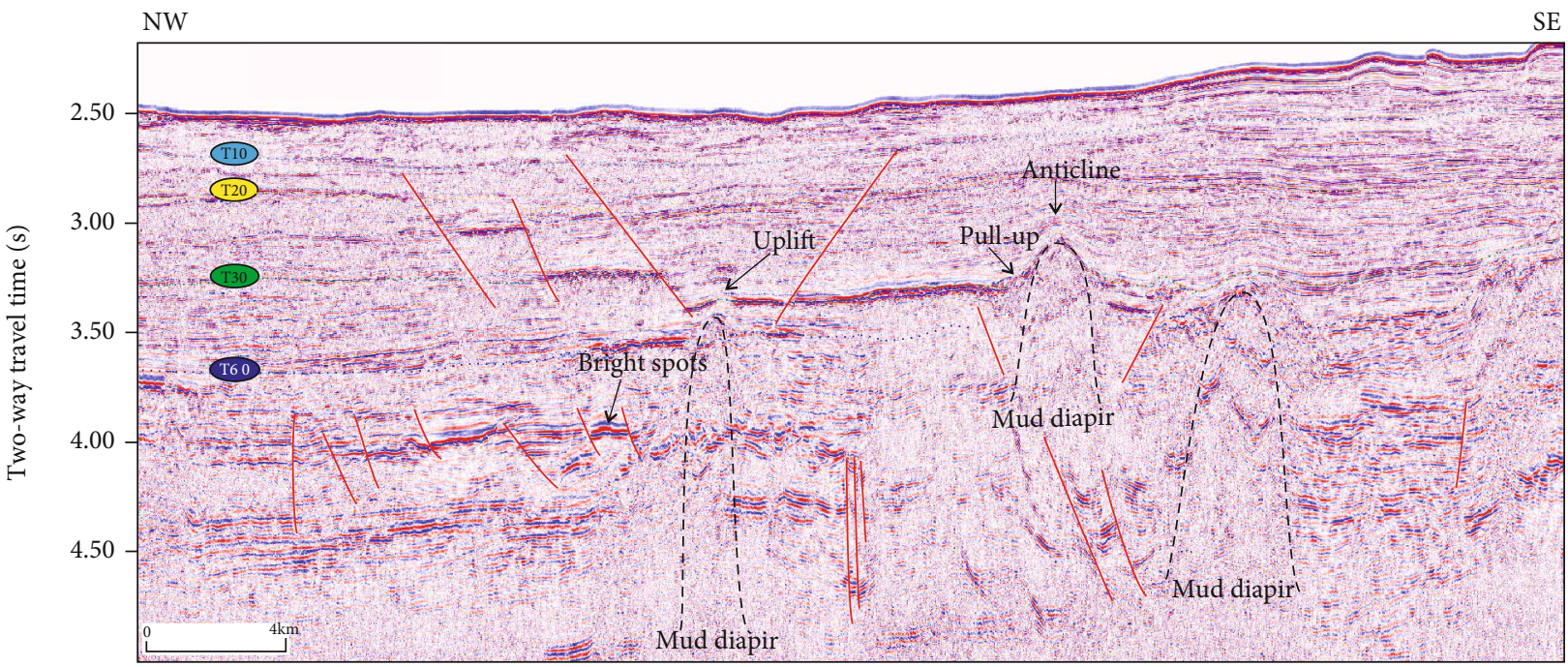

(a)

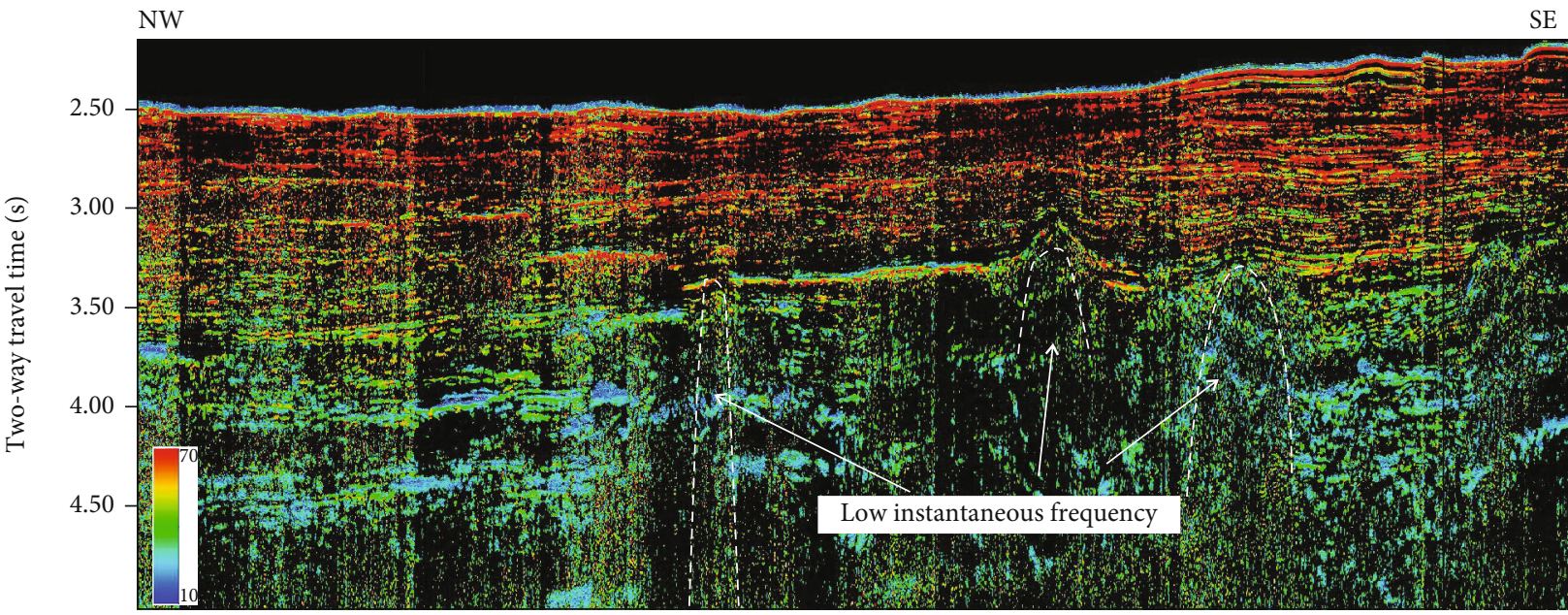

(b)

FIGURE 4: (a) Seismic profile over the Qiongdongnan Basin. Mud diapirs puncture into the Neogene strata in a vertical columnar or chimneylike form. Diapir intrusions caused arch-up deformation of the overlying strata and "uplift" of the wall layers. The interior of the diapirs is characterized by blank, clutter, bright spots and other abnormal seismic reflection characteristics. (b) Instantaneous frequency distribution map. The blank or cluttered reflection area presents a low instantaneous frequency from the deep to shallow part on the instantaneous frequency distribution profile, which is significantly different from the higher instantaneous frequency value of the surrounding rock.

$\sim 1000 \mathrm{~km}^{2}$. Mud diapirs are mainly distributed in the southwestern side of the central part of the Baiyun sag (Zhuer depression) and extend $\sim \mathrm{NWW}$, which is generally consistent with the direction of the fault system developed in the late Miocene $[65,66]$. The Shenhu area in the Baiyun sag of the Pearl River Mouth Basin displays typical diapiric structures. Mud diapirs are mainly developed in Paleogene strata pierced vertically through the T3 interface (Figure 5(a)). The tops of the mud diapirs reach the Miocene stratum, causing ductile arching of the overlying sedimentary layer. In addition, numbers of gas chimneys have been found in the Pearl River Mouth Basin. We can recognize two gas chimneys near the diapir in Figure 5(a). The left one shows pulldown continuous reflection inside while the right one shows pull-down and blank zone inside. Mud diapirs give lower instantaneous frequency values on the instantaneous frequency profiles (Figure 5(b)). Many mud volcanoes have been found in the southwestern area of the Dongsha Islands, which distribute in a SWW-NEE direction, with singlemound widths of $0.5-2.0 \mathrm{~km}$ and heights of $50-200 \mathrm{~m}$. There are more than 100-kilometer-wide mud volcanoes in the study area, and the largest one was 5 kilometers wide and 200 meters high $[43,67]$. In the Dongsha Sea, the seismic profile reveals a thin Cenozoic sedimentary cover and the uplift of the Mesozoic basement caused the upward deformation of the overlying sediment (Figure 6).

4.4. Characteristics of Mud Volcanoes and Diapirs in the Southwest Taiwan Basin. Mud volcanoes and diapirs are widely distributed in the Southwest Taiwan Basin. Terrestrial mud volcanoes primarily occur in the hilly areas of southwestern Taiwan, whereas underwater mud volcanoes are mainly concentrated in the deep waters of the southern depression of the investigated basin and are characterized 


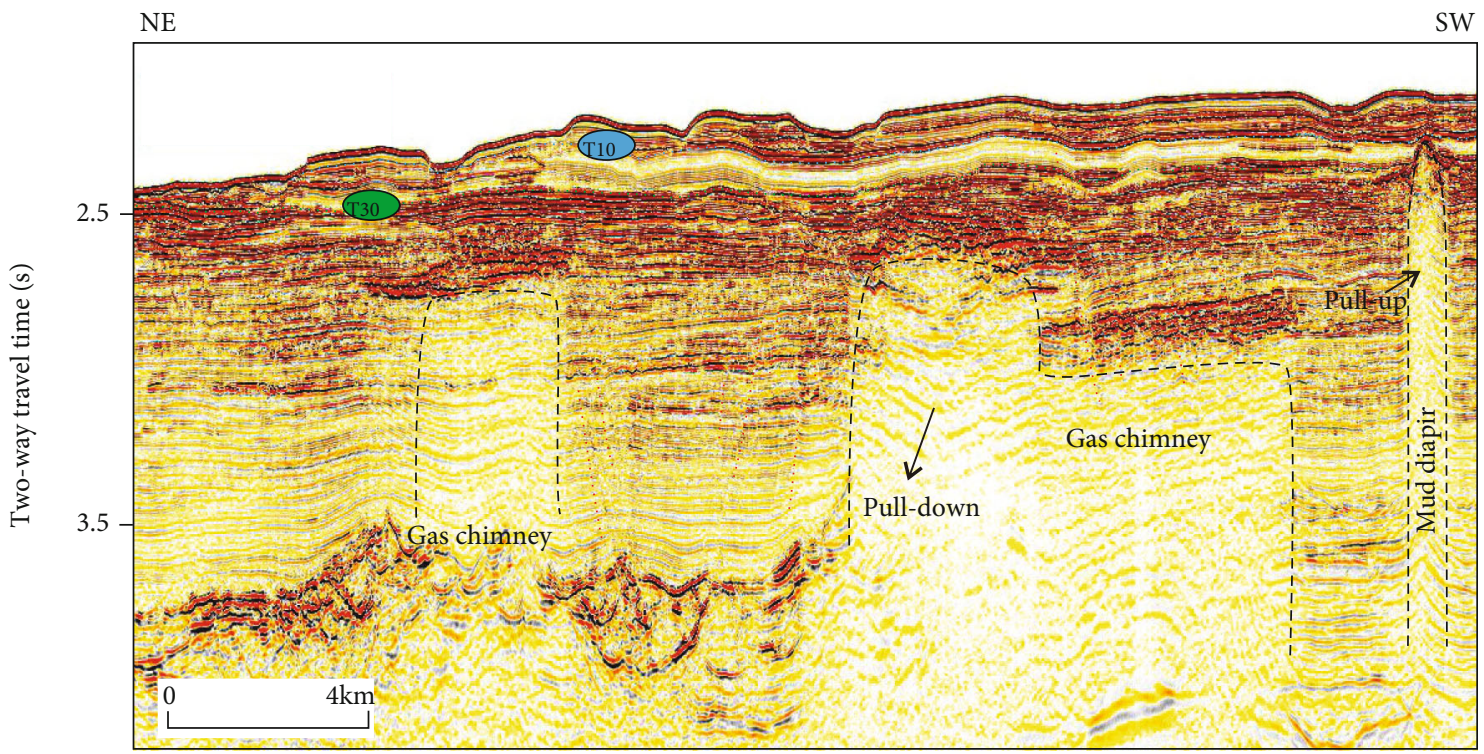

(a)

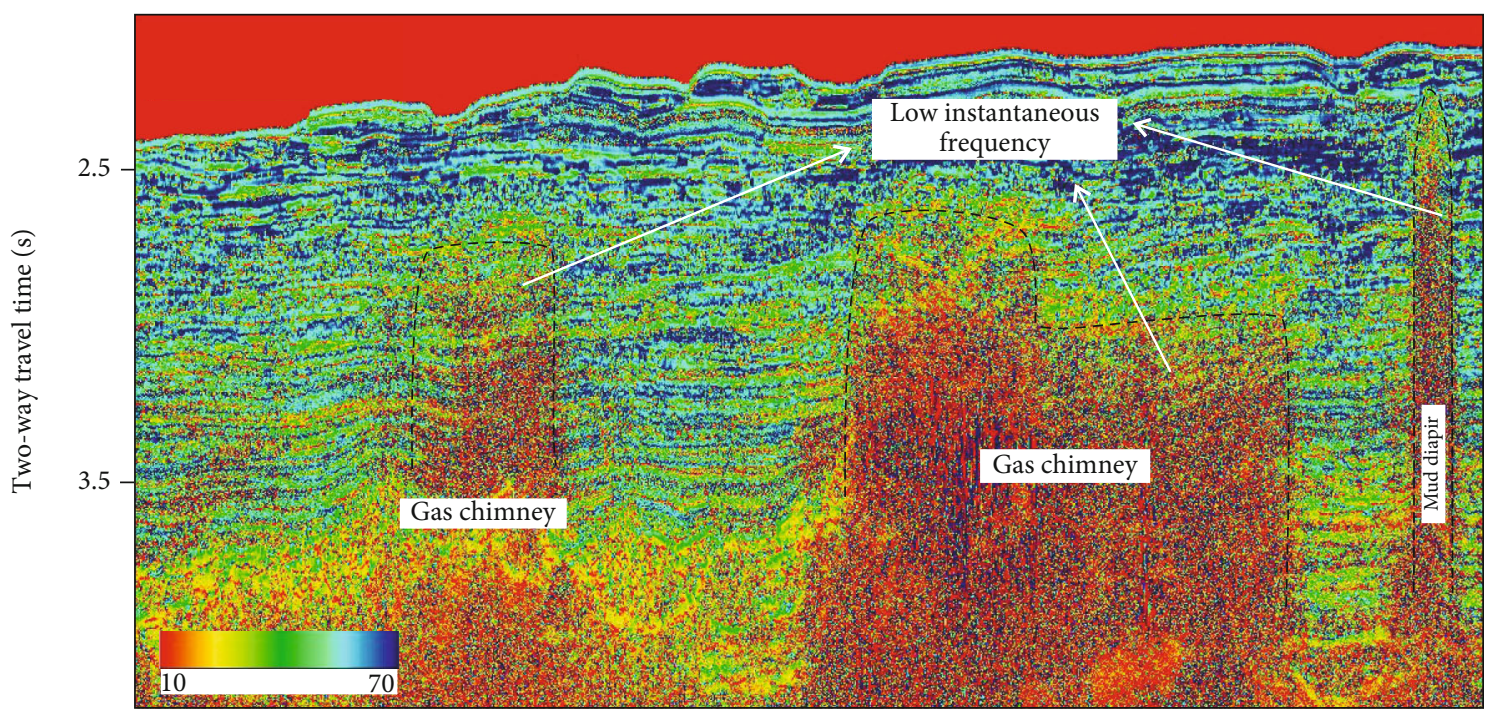

(b)

Figure 5: (a) Seismic profile over the Shenhu hydrate exploration area in Baiyun sag of Pearl River Mouth Basin. One mud diapir and two gas chimneys can be recognized in the profile. Mud diapir developed in the Paleogene strata, with a vertical columnar piercing T3 interface and reaching the Miocene strata causing plastic deformation of overlying sediments. (b) Internal appearance of the mud diapir on the instantaneous frequency profile exhibiting a low instantaneous frequency.

by a larger size than that of their onshore equivalents [68]. A total of 94 submarine mud volcanoes have been reported from the Southwest Taiwan Basin and are subdivided into four sectors [69], with each mud volcano sector consisting of several mud volcanoes and most of them are located in fault zones $[39,68]$. Based on a comprehensive analysis of multichannel seismic reflection (MCS) profiles, multibeam bathymetric data, and deep-towed sidescan sonar data, 10 NNE-SSW-oriented mud diapir ridges and 13 mud volcanoes which developed over these mud diapirs were identified in the Gaoping slope zone of the Southwest Taiwan Basin [39]. Some of these mud volcanoes and diapirs are still active $[39,70,71]$. The lengths of the mud diapir ridges vary from 3.9 to $56.5 \mathrm{~km}$ and their widths from 1.6 to $8.3 \mathrm{~km} \mathrm{[39].} \mathrm{They}$ range in height between 65 and $345 \mathrm{~m}$, having a pedestal diameter of $\sim 680 \mathrm{~m}$ to $\sim 4100 \mathrm{~m}[19,21,39]$. The fluid leakage structures in the Gaoping slope zone were formed during the Paleogene and its shallow strata of Paleogene age due to amplified intrusion of mud slurry exudates, gradually increasing the degree of expansion and piercing of the upper stratigraphic horizons of the investigated basin ([39], Figures 7 and 8).

\section{Discussion}

5.1. A Comparison of the Geological Aspects of the Investigated Piercement Structures. Mud volcanoes and diapirs in the continental marginal basins of the northern South 


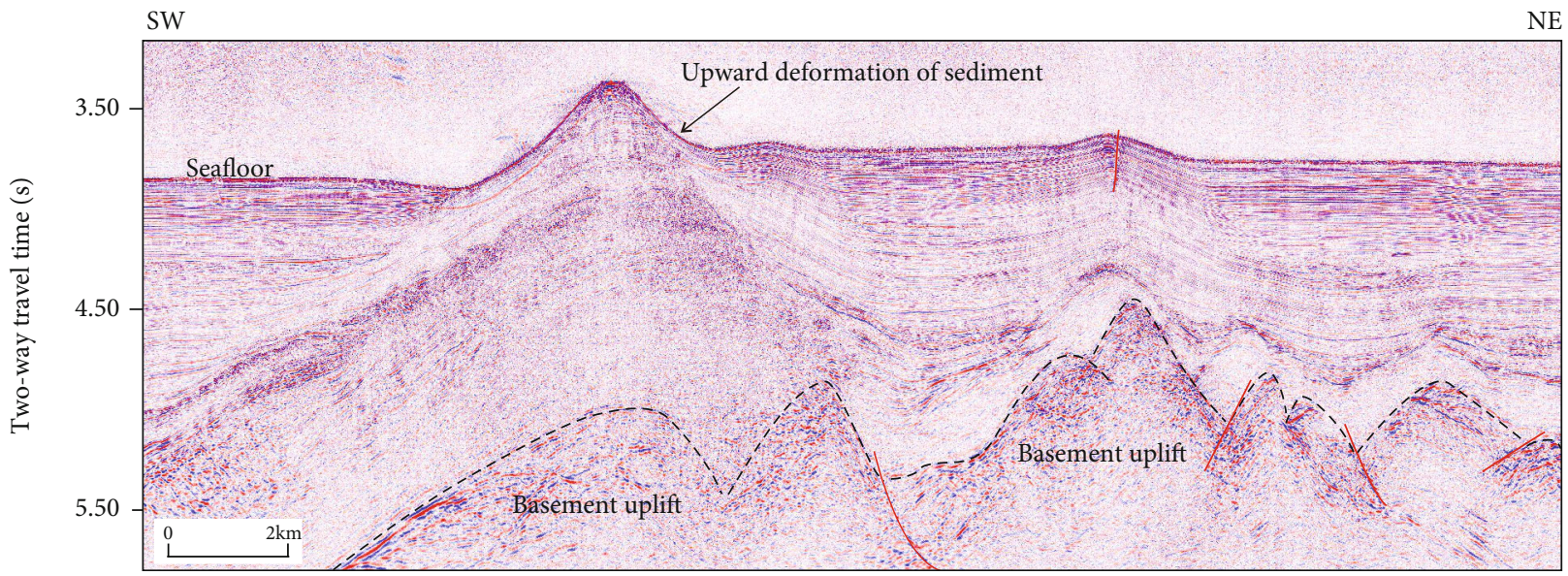

FIGURE 6: Seismic profile of the Dongsha Islands. The seismic profile reveals a thin Cenozoic sedimentary cover, and the uplift of the Mesozoic basement caused the upward deformation of the overlying sediment.

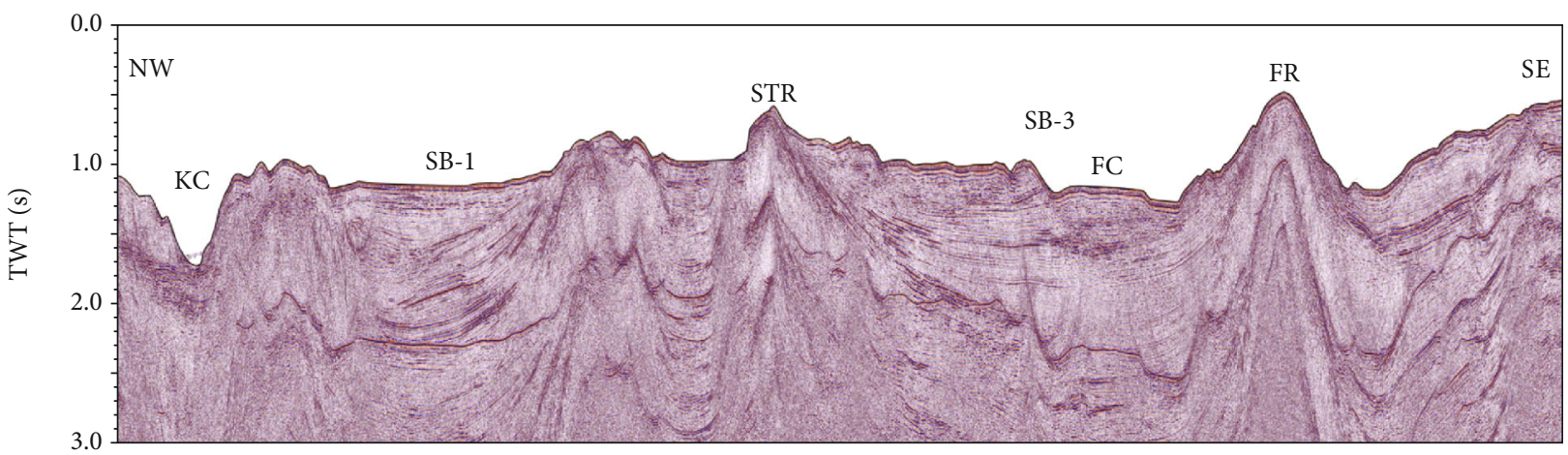

(a)

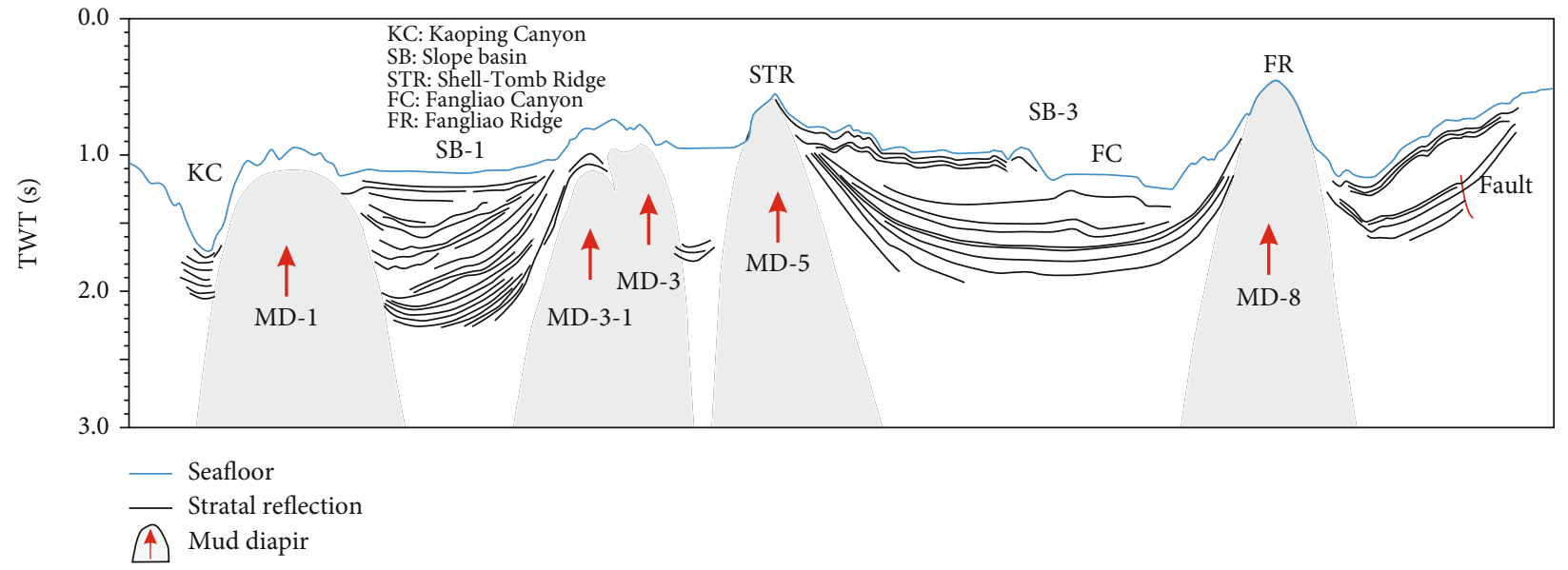

(b)

Figure 7: (a) Seismic profile and (b) the interpreted seismic profile over the Southwest Taiwan Basin. Five mud diapirs are present in this profile, and the two on the right have pierced through thick sediments and are exposed at the seafloor, and the surrounding rock is uplifted, obviously (modified from [39]).

China Sea are characterized by noteworthy differences in their distribution, morphology, and piercing horizon (Figure 9). Mud diapirs in the Qiongdongnan Basin are randomly distributed but occasionally occur in groups. In con- trast, mud volcanoes and diapirs in the Southwest Taiwan Basin are distributed alongside the strike of deep faults and mud diapirs are arranged in 5 rows in an echelon pattern along the long axis of Yinggehai Basin. The largest mud 


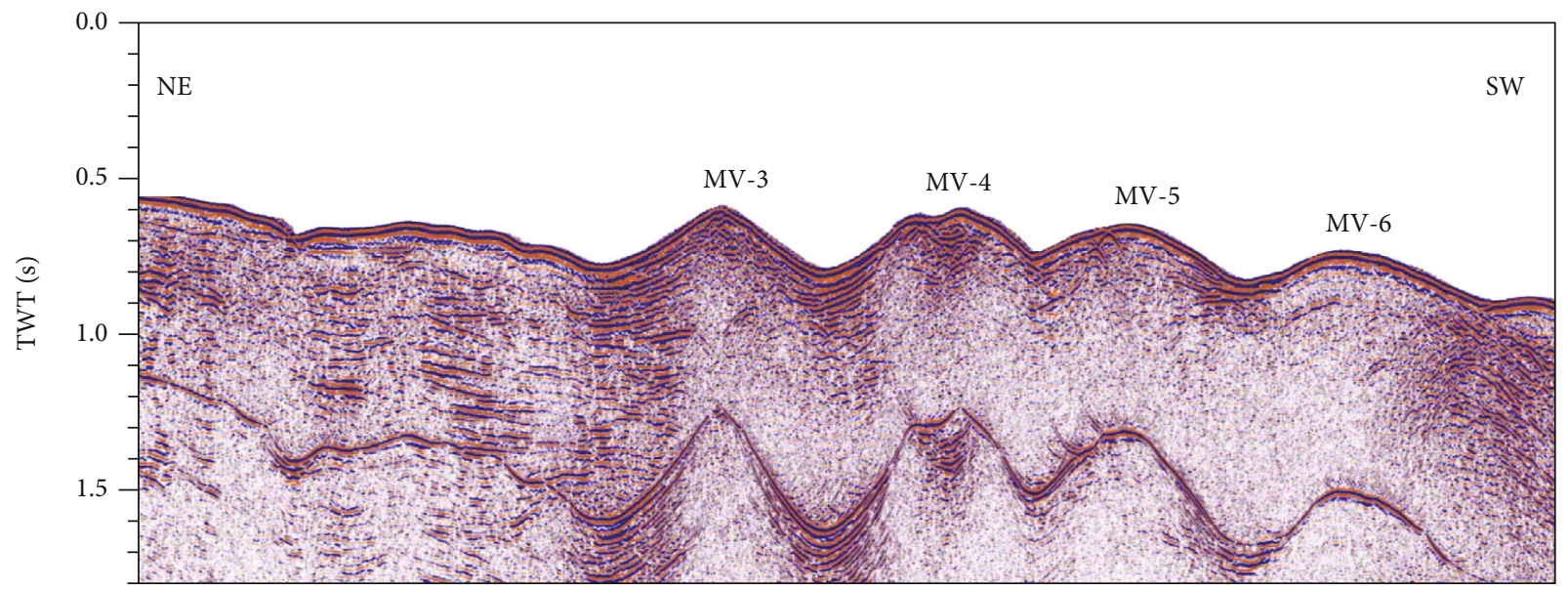

(a)

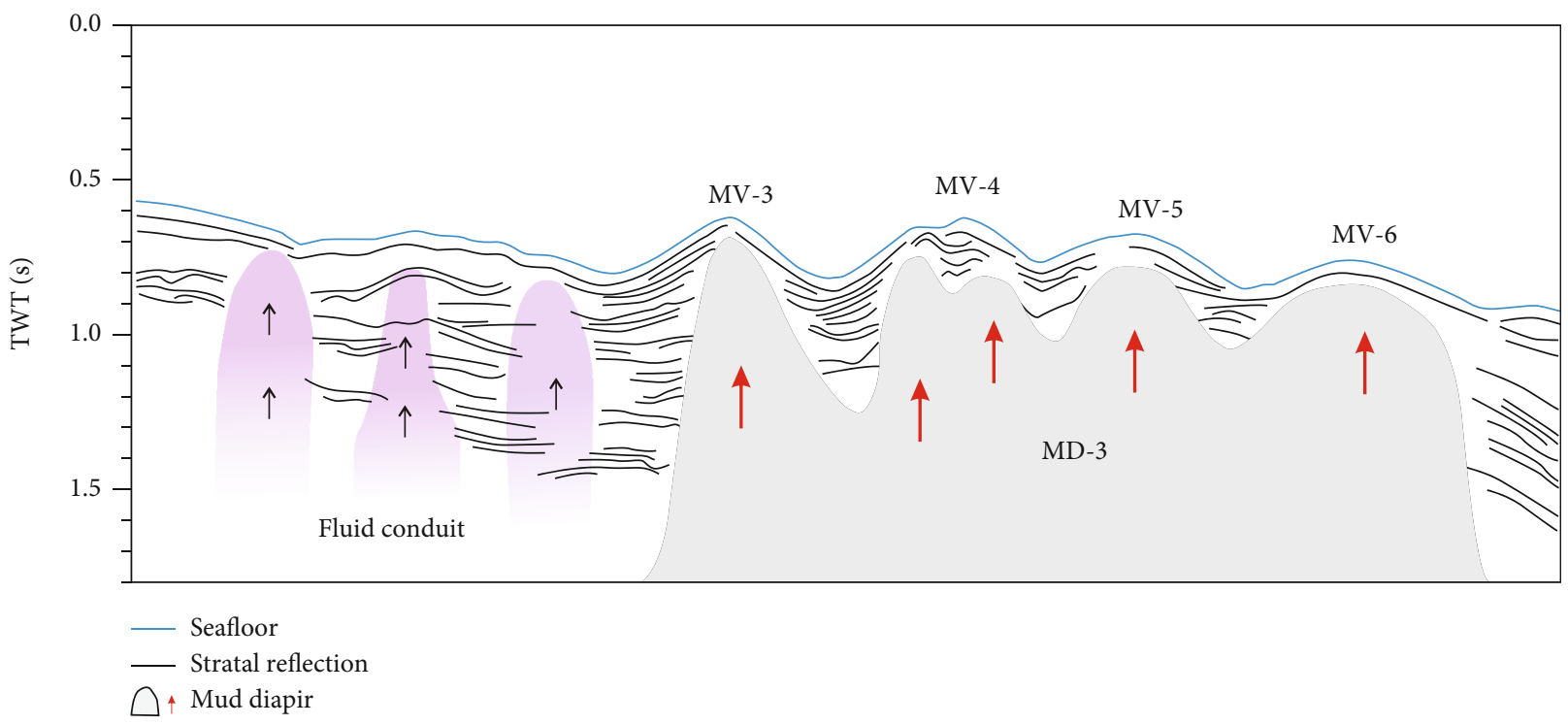

(b)

FIGURE 8: (a) Seismic profile and (b) the interpreted seismic profile of Southwest Taiwan Basin. Four mud volcanoes have developed on the mud diapir, and the surrounding rock is uplifted, mildly. Some fluid conduits can be noted on the profile (modified from [39]).

diapir in the Baiyun sag of the Pearl River Mouth Basin covers an area of $\sim 1000 \mathrm{~km}^{2}$ and has a maximum intrusion height of $\sim 8 \mathrm{~km} \mathrm{[66],} \mathrm{and} \mathrm{the} \mathrm{largest} \mathrm{mud} \mathrm{diapirs} \mathrm{in} \mathrm{the} \mathrm{Ying-}$ gehai basin covers an area of more than $700 \mathrm{~km}^{2}$. On the contrary, mud volcanoes distributed in the southwestern part of the Dongsha Sea have much smaller diameters $(0.5-2 \mathrm{~km})$ and heights (50-200 m; [43]). Furthermore, the size and piercing horizon of investigated fluid seepage structures also differ among the different basins or even within a single basin (Figure 9). For instance, the fluid leakage structures developed in the Southwest Taiwan Basin vary significantly in size, some of mud diapirs within the basin with only a few meters of punctured but others pierce through shallow sedimentary formations and even close to the seafloor [39]. In the Yinggehai Basin, invasive activity pierces the T40-T30 seismic reflection interface in the Dongfang district (Figure 3), whereas mud diapirs almost penetrate the T14 seismic emission interface in the Changnan district [49].
Despite the differences among the mud volcanoes and diapirs in the continental marginal basins of the northern South China Sea, some interesting similarities exist between the investigated piercement structures and other typical mud volcano and diapir occurrences from elsewhere. For example, the distribution of mud volcanoes along the Berca-Arbanasi zone in Romania is controlled by a large anticline structure and the distribution of mud volcanoes along the Pede-Apennine margin in Italy is controlled by a thrust fault $[9,72]$. In a similar way, most of mud volcanoes and diapirs in the Yinggehai, Qiongdongnan, Pearl River Mouth, and Southwest Taiwan Basins are structurally controlled by regional fault systems, just like mud diapirs in Yinggehai Basin, Baiyun sag (Table 1), and mud volcanoes along the Gutingkeng anticline and Chishan Fault [73], except mud volcanoes distributed in the southwestern part of the Dongsha Islands in the Pearl River Mouth Basin. 


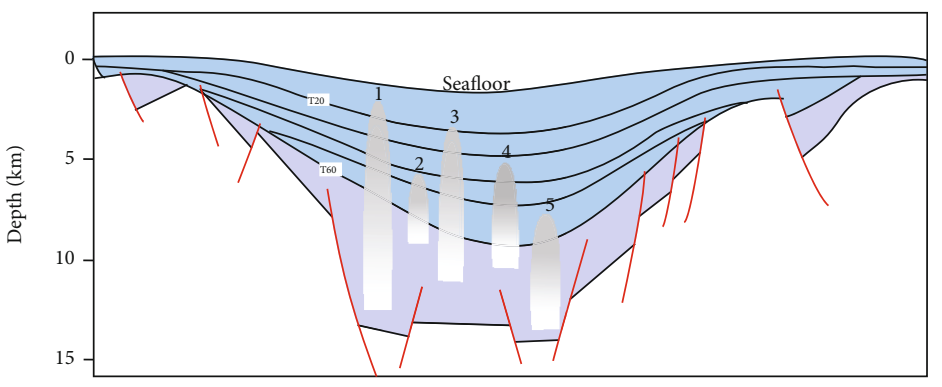

(a)

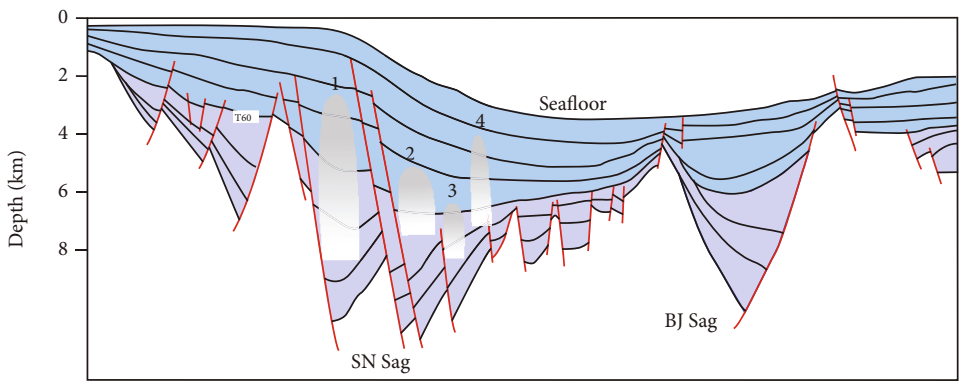

(b)

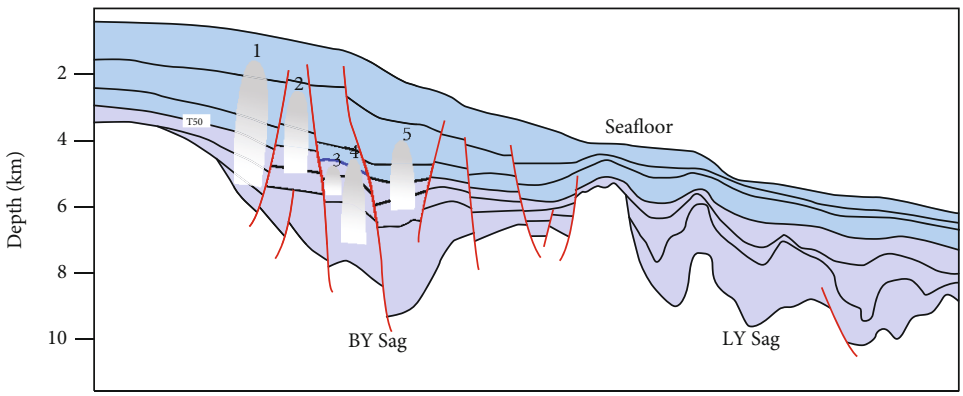

(c)

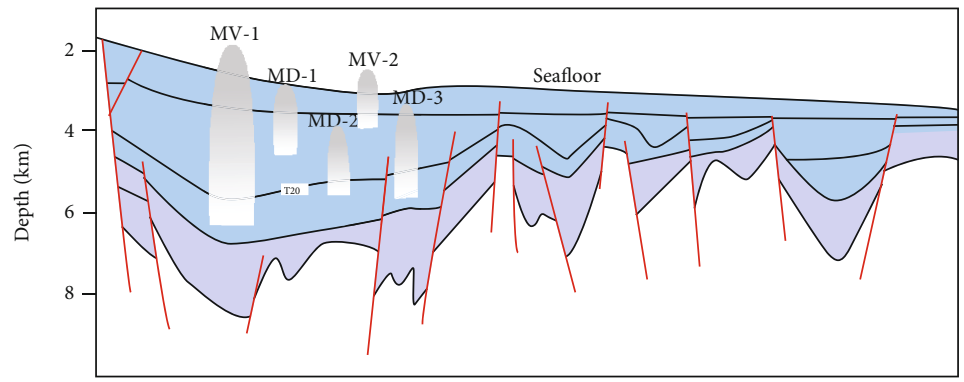

(d)

Figure 9: (a) Developmental pattern of mud diapirs in Yinggehai Basin. Mud diapirs developed based on the sediments from the Neogene Sanya Formation to Yinggehai Formation. Mud diapirs vertically pierce through to the Quaternary strata. The grey-purple part indicates the Paleogene stratum. The source of MD-1 and MD-5 is deeper than other mud diapirs, and MD-1 pierces the shallower stratum; the sources of MD-2, MD-3, and MD-4 are shallow, and they pierce through strata at different depths. (b) Developmental pattern of mud diapirs in Qiongdongnan Basin. Mud diapirs are derived from Paleogene (Eocene-Oligocene) shale, which penetrates the Neogene strata vertically. The grey-purple part indicates the Paleogene stratum. The source of MD-1 and MD-3 is deeper than other mud diapirs, and MD 1 pierces the shallower stratum; the sources of MD 2 and MD-4 are shallow, and they pierce through strata at different depths. (c) Developmental pattern of mud diapirs in Baiyun sag of Pearl River Mouth Basin. The source of the diapir material is Paleogene (EoceneOligocene) shale, and diapirs pierce the Neogene strata vertically. The grey-purple part indicates the formation below the T50 interface. The source of MD-1 and MD-4 is deeper than other mud diapirs, and MD-1 pierces the shallower stratum; the sources of MD-2, MD-3, and MD-5 are shallow, and they pierce through strata at different depths. (d) Developmental pattern of mud volcanoes and mud diapirs in Southwest Taiwan Basin. The source of mud volcanoes and mud diapirs is Neogene (Miocene and Pliocene) shale, and the fluid penetrates through the Quaternary strata or the seafloor. The grey-purple part indicates the Paleogene stratum. MV-1 and MV-2 represent mud volcanoes of different scales; MD-1 indicates the shallow diapir of the source, and the vertical piercing is close to the seabed; MD-2 and MD-3 have deeper sources and pierce through different horizons. 
Piercement structures in the northern continental marginal basin of the South China Sea predominantly occur in deep-water areas covered by thick sediment (Figure 1). From west to east, the mud volcanoes and diapirs are distributed in the central depression, the deep-water areas of the southern depression, in the Baiyun sag, the deep-water areas of the southwestern of the Dongsha Islands, and the deep-water areas in the southern depression of the basin. This may be related to the high temperature and overpressure caused by the rapid subsidence and later hydrocarbon generation in deep-water areas covered by sedimentary sequences of substantial thickness.

5.2. The Influence of Overpressure on the Formation Process of Piercement Structures. The Cenozoic sedimentary sequences hosted in the marginal basins of the South China Sea show evidence of rapid subsidence and sedimentation. These thick Cenozoic sediment sequences contributed to the establishment of high $T$ and overpressure conditions in the investigated marginal basins.

More specifically, the Yinggehai Basin is characterized by a high sedimentation-deposition rate which is conducive to the development of overpressure in the Paleogene and Neogene strata. The central mud diapir belt was generated under strong overpressure and has a large formation pressure coefficient. The formation pressure coefficient of most areas in the Yinggehai Basin is above 2.0, and the biggest formation pressure coefficient in the central mud diapir belt can reach to 2.28 (Table 2). Moreover, geophysical and geochemical studies suggest that the source of mud diapirs in the Yinggehai Basin may be the Neogene Sanya Formation to the bottom of the Yinggehai Formation $[49,68]$, which is equivalent to the position of the initiation of overpressure in the Yinggehai Basin. Seismic profiles also reveal that the puncture layer of mud diapirs in the Yinggehai Basin encompasses Neogene to Quaternary strata.

In the Qiongdongnan Basin, the geothermal gradient is high and overpressure is generally developed in the central part of the basin and the central depression in the southern side of the basin $[62,74]$. The anomalous overpressure in the central depression is mainly developed in mudstones of the Paleogene to Meishan Formation of Miocene, with a pressure coefficient of 1.5-2.2 [75]. Geophysical and geochemical evidences suggest that the source material of mud diapirs/mud volcanoes in the Qiongdongnan Basin is most likely consists of shales in Eocene and Oligocene [49], which is equivalent to the position of the initiation of overpressure in the Qiongdongnan Basin. Seismic profiles reveal that the diapir puncture layer in the Qiongdongnan Basin encompasses Paleogene to Neogene strata.

Neotectonic movements since the late Miocene have obliterated any signs of extremely high $P$ in most areas of the Pearl River Mouth Basin. However, low-overpressure still exists in the deep-water areas of the southern slope of the basin [76]. Overpressure simulation analysis carried out by Shi et al. [76] revealed that during the sedimentary evolution of the Baiyun sag, overpressure was only 9.0 MPa, which may not be high enough to drive the flux of fluids in the Baiyun sag. Geological and geochemical studies suggest that the source material of mud diapirs in the Pearl River Mouth Basin may be Eocene and Oligocene argillite [49]. Furthermore, seismic profiles reveal that mud diapirs in the Baiyun sag intruded the overlying strata up to the level of the Quaternary sedimentary layer (like mud diapirs in Shenhu hydrate exploration area (Figure 5(a))).

The Southwest Taiwan Basin has undergone a long period of compression. The large amount of terrigenous clastic material coupled with the high sedimentary filling rate in the Southwest Taiwan Basin resulted in a rapid deposition of fine-grained materials of Miocene to Pliocene shales. And undercompaction resulted by high filling rate, coupled with the genesis of hydrocarbons, finally led to the formation of an abnormal high $T$ and overpressure environment, providing a significant source of muddy material and energy for the formation of mud volcanoes and diapirs in Southwest Taiwan Basin. Geophysical and geochemical investigations suggest that the source material of mud diapirs and mud volcanoes in the Southwest Taiwan Basin was most likely Miocene and Pliocene argillite, penetrating the overlying strata up to the level of Quaternary sediments to form mud volcanoes.

In conclusion, the distribution of mud volcanos and diapirs is closely related to the distribution of overpressure in the basin, except in the Pearl River Mouth Basin.

5.3. Controls on Variations in the Type and Mode of Piercement Structures. The genesis of mud volcanoes and diapirs in the northern continental margin of the South China Sea is generally controlled by quite similar geological processes. Consequently, the question arises as to what causes the different geological modes of occurrence of the investigated piercement structures. The reasons for this difference are most likely the following: (1) variations in the regional tectonic setting, leading to a different stress status in each basin, and (2) variations in the type and thicknesses of the sediment filling each basin, and difference of overpressure.

In general, most mud volcanoes and diapirs are formed in accretionary wedges, some occur in extensional settings, and a few are linked to both convergent and divergent environments [39]. The formation and evolution process of the Yinggehai Basin is controlled by the NW strike-slip Red River Fault Zone, and mud diapirs distributed in the central depression area are in the form of en echelon along the NW axis of the basin. The formation of the Qiongdongnan and Pearl River Mouth Basins was mainly controlled by extensional rifting and uplift structures formed during the rift period, among which the Pearl River Mouth Basin is controlled by the dextral tensional-torsional environment in the Early Cenozoic [62]. A series of NWW-oriented strike-slip faults are produced within the Baiyun sag [49] consistent with the distribution of mud diapirs/volcanoes. And the genesis and evolution history of the Southwest Taiwan Basin are largely controlled by a subduction-related reverse fault system. The distribution of mud volcanoes in the Southwest Taiwan Basin and the southwest part of Taiwan Island is obviously related to the distribution of the strike-slip fault or anticline [77]. Consequently, mud diapirs distributed in the Yinggehai Basin may be related to strike-slip tectonism, 
TABle 2: Characteristics of the Yinggehai Basin, Qiongdongnan Basin, Pearl River Mouth Basin, and Southwest Taiwan Basin in the northern South China Sea $[43,57,65,67,76]$.

\begin{tabular}{|c|c|c|c|}
\hline & Sediment thickness of Cenozoic & Characteristics of overpressure & $\begin{array}{l}\text { The age of the source } \\
\text { layers }\end{array}$ \\
\hline $\begin{array}{l}\text { Yinggehai } \\
\text { Basin }\end{array}$ & $\begin{array}{l}\text { The maximum deposition thickness of Tertiary } \\
\text { and Quaternary in the central depression } \\
\text { exceeds } 17000 \mathrm{~m} \text {. }\end{array}$ & $\begin{array}{l}\text { Overpressure is generally developed in Tertiary, } \\
\text { and the pressure coefficient }{ }^{*} \text { in most areas of } \\
\text { the central mud diapir belt is more than } 2.0 \text {, } \\
\text { and the maximum is } 2.28 \text {. }\end{array}$ & $\begin{array}{l}\text { Neogene Sanya } \\
\text { Formation to the } \\
\text { bottom of the } \\
\text { Yinggehai Formation }\end{array}$ \\
\hline $\begin{array}{l}\text { Qiongdongnan } \\
\text { Basin }\end{array}$ & $\begin{array}{l}\text { The Cenozoic sediment thickness is up to } \\
11000 \mathrm{~m} \text {. The maximum thickness of } \\
\text { Paleogene and Neogene is over } 7000 \mathrm{~m} \text { and } \\
3000 \sim 5000 \mathrm{~m} \text {, respectively. }\end{array}$ & $\begin{array}{l}\text { The overpressure is generally developed in the } \\
\text { center of the basin. The pressure coefficient* of } \\
\text { the central depression in the deep-water area in } \\
\text { the south, Ledong-Lingshui sag, and Songnan } \\
\text { sag reaches } 1.5-2.2 \text {, over } 2.2 \text {, and } 2.0 \text {, } \\
\text { respectively. }\end{array}$ & Eocene and Oligocene \\
\hline \multirow[t]{2}{*}{$\begin{array}{l}\text { Pearl River } \\
\text { Mouth Basin }\end{array}$} & $\begin{array}{l}\text { The maximum thickness of Cenozoic is over } \\
10000 \mathrm{~m} \text {, of which the maximum thickness of } \\
\text { Paleogene, Neogene, and Quaternary is over } \\
6000 \mathrm{~m}, 3500 \mathrm{~m} \text {, and less than } 400 \mathrm{~m} \text {, } \\
\text { respectively. }\end{array}$ & $\begin{array}{l}\text { The abnormal overpressure has disappeared in } \\
\text { most areas, and only a small overpressure exists } \\
\text { in marine mudstone strata below the } \\
\text { continental slope and deep source rock strata. }\end{array}$ & Eocene and Oligocene \\
\hline & $\begin{array}{l}\text { Dongsha area is characterized by thin } \\
(\sim 0.5 \mathrm{~km}) \text { Cenozoic sediments and thick (up to } \\
5 \mathrm{~km}) \text { Mesozoic strata. }\end{array}$ & $\begin{array}{l}\text { The maximum overpressure once possessed by } \\
\text { Baiyun sag is only } 9.0 \mathrm{MPa} \text {. }\end{array}$ & Mesozoic \\
\hline $\begin{array}{l}\text { Southwest } \\
\text { Taiwan Basin }\end{array}$ & $\begin{array}{l}\text { The Cenozoic thickness of the northern } \\
\text { depression and southern depression is } 5000 \text { - } \\
7000 \mathrm{~m} \text { and generally } 5000 \mathrm{~m} \text {, respectively, and } \\
\text { the maximum thickness of the sedimentary } \\
\text { center near Kaohsiung is more than } 10000 \mathrm{~m} \text {. }\end{array}$ & $\begin{array}{l}\text { Abnormal high temperature and overpressure } \\
\text { are develop in the basin. }\end{array}$ & Miocene and Pliocene \\
\hline
\end{tabular}

*Formation pressure coefficient $\left(\alpha_{p}\right)=$ formation pressure $\left(P_{P}\right) /$ hydrostatic pressure $\left(P_{h}\right), \alpha_{p}$ of YGHB and QDNB refer to [49, 75], respectively.

mud diapirs in the Qiongdongnan and Pearl River Mouth Basins may be linked to an extensional geotectonic regime and in Southwest Taiwan Basin, and mud volcanoes and diapirs may be linked to a strike-slip and compressional setting. According to the distribution and scale of mud volcanoes and diapirs mentioned above and previous research results [39], the extrusion background and strike-slip stress may be of key importance to the genesis of mud volcanoes and diapirs, but differences in stress field do not directly lead to the difference in the scale of mud volcanoes or diapirs (Table 1, mud diapirs in Yinggehai or Southwest Taiwan Basins are not larger than those in the Pearl River Mouth Basin), and the trends of tectonic (such as faults) in these basins can affect the distribution of mud volcanoes and diapirs.

Thick Cenozoic sediments are generally deposited in the deep-water area of the northern South China Sea, which commonly show characteristics of rapid subsidence and sedimentation. These fine-grained sediments of Cenozoic are presumed to comprise the essential material for the genesis of mud volcanoes and diapirs $[49,68]$. The material sources of mud diapirs in the Yinggehai Basin are mainly mud shale of Miocene and Pliocene, but the source layers of mud volcanoes or diapirs in the Qiongdongnan Basin and Pearl River Mouth Basin are Eocene and Oligocene mud shale [49]. Particularly, geochemical and isotopic analysis shows that finegrained and loose sediments of Mesozoic age provided the essential sources for the genesis of mud volcanoes in the Dongsha area [43]. Furthermore, thick Miocene and Pliocene marine shales and argillites probably provided the geological material for the formation of diapiric structures in the Southwest Taiwan Basin [49]. We conclude that source materials of the fluid seepage structures in the investigated sedimentary basins were of similar lithology but were derived from different stratigraphic horizons.

The thickness of the sedimentary sequence of a basin may affect the formation of piercing structures to some extent (we used drilling datum to calculate the average depth of the source layer of mud volcanoes/mud diapirs in Yinggehai, Qiongdongnan, Pearl River Mouth, and Southwest Taiwan Basins in Table 2). For basins filled with thick sedimentary, it may require more power to move fluids along a fracture to the surface (physical simulation results of our research group can verify it (unpublished)). Assume that there are two sets of formations with similar pressure and the heights of the intrusion are the same, for areas where we have a thinner deposition thickness, mud may travel to the surface to form mud volcanoes. In contrast, in areas covered by thick sediment deposits, mud diapirs may be formed. The study of the seismic profiles of mud diapirs (with multiple periods of activity) from the Qiongdongnan Basin and of mud volcanoes (superimposed on mud diapirs) from the Southwest Taiwan Basin indicates that fluid intrusionrelated activities can pierce shallower sediments or even giving rise to the formation of mud volcanoes if the fluid penetrates the seabed [39].

Compared to other basins in the northern continental margin of the South China Sea, the Yinggehai Basin is characterized by relatively significant overpressure of the 
sedimentary strata and affected by large-scale strike-slip faults. However, this basin hosts a large number of mud diapirs instead of mud volcanoes, which may be attributed to a thick Cenozoic sedimentary sequence. Due to the deposition of thick Quaternary sediments on thick Neogene mud shales, it becomes more difficult for fluids to invade the seafloor to form mud volcanoes. For the Southwest Taiwan Basin, with analogous overpressure status and stress background to those of the Yinggehai Basin, it is likely that a relatively thin Cenozoic sedimentary cover favored the genesis of mud volcanoes. From the seismic profiles mentioned above (Figures 3-6), it can be found that mud diapirs and mud volcanoes are formed by the upward migration of deep fluids into the overlying strata, and the difference between them is only whether they reach to the seafloor or the surface and accumulate to form a mound structure. We can regard mud diapir as the intermediate link of the formation process of mud volcano. Therefore, we do not rule out the possibility of the formation of mud volcanoes in the Yinggehai Basin after multiple diapir activities.

Overall data indicate that the extrusion background and strike-slip stress may be of key importance to the genesis of mud volcanoes and diapirs, but differences in stress field do not directly lead to the difference in the scale of mud volcanoes or diapirs. The thickness of the sedimentary cap (above the mud source layer) and the existence of deep faults in a geological basin also play a fundamental role in determining the type of the ensuing piercing structure.

\subsection{The Factors Controlling the Genesis of Fluid Leakage} Structures. The genesis of mud volcanoes has been the subject of many frontline studies and remains a hotly debated issue among geologists, many of whom passionately defend theories about the formation of such piercement structures. Briefly, two elements are essential for the genesis of a mud volcano; namely, thick muddy strata with high pore-fluid $P$ (overpressure) and substantial power required to enable mud volcanic eruption (i.e., seismic activity; [78-80]). Zhang [49] carried out a detailed investigation on the formation conditions and genetic mechanisms of mud volcanoes and diapirs in the northern continental margin of the South China Sea. He concluded that the genesis of piercing structures in the Yinggehai, Qiongdongnan, and Southwest Taiwan Basins and the Baiyun sag of the Pearl River Mouth Basin is primarily controlled by the establishment of a high $T$ and overpressure environment, suitable tectonic stress, sufficient supply of mud, and a well-developed fracture system.

By the reasoning in the foregoing paragraph, it is inferred that regional tectonic, sedimentary sequence, and overpressure are of central importance in the formation of fluid seepage structures. In particular, faults in the central depression of the Yinggehai Basin are not very extensive, but local overpressure is significant. The Pearl River Mouth Basin is generally characterized by extensional rifting. However, low overpressure is remarked only in a small area. Overpressure is moderate in the Qiongdongnan Basin. Among them, faults are not well-developed in the Ledong-Lingshui sag with high and widespread overpressure (overpressure characteristics of these basins are recorded in Table 2), but faults are widely developed in the Changchang sag with local and weak overpressure [75]. The Pearl River Mouth Basin has been affected by neotectonic movements, abnormally high $P$ has disappeared, and the overpressure in the Baiyun sag during the sedimentary evolution of the Pearl River Mouth Basin has been estimated to be only 9.0 MPa [76], which is not sufficient to drive diapiric activities. Nevertheless, the large number of mud diapirs in the Pearl River Mouth Basin indicates that extremely high pore-fluid $P$ may not be the only driving force for the formation of fluid seepage structures in the region. A system of NWW-striking fractures most likely aided the formation of diapiric structures in the Baiyun sag area.

Mud volcanoes are not true volcanoes as they do not produce lava and are not associated with igneous activity. Since mud volcano systems and magma systems have similar mechanisms and are controlled by similar processes $[9,81$, 82], a mathematical model developed to quantify the eruption mechanism of a magmatic volcano may be quite useful for understanding the commencement, buildup, and operation of a mud volcano as well. Cheng et al. [83] used a numerical model to apply the finite element and finite difference methods, to study the effects of magma viscosity, effective density difference, and depth on minimum overpressure (minimum magma chamber pressure required for magma migration to the surface). He concluded that an increase in the tectonic stress and effective density difference of the vertical fault plane can reduce the minimum overpressure and the minimum overpressure will increase due to an increase in magma viscosity and model depth.

These results have significant implications for the mechanisms that control the formation of mud volcanoes or diapirs. More specifically, the depth of a mud source layer, the regional tectonic stress, and physical properties of the mud itself can affect the process of moving mud slurry to the surface. If the depth of the mud source layer (thickness of sediment), the stress, and physical properties of the mud itself are constant, fluid will rise to the surface to form a mud volcano once the overpressure of the mud source layer becomes greater than the minimum overpressure required to move the slurry to the surface (Figure 10). If overpressure is less than the minimum overpressure, the mud slurry will intrude the overlying layers without reaching the surface. In this case, a mud diapir will be produced. This is in agreement with the notion we discussed above that the thickness of a sediment affects the type of the fluid leakage structure that will be formed. A deep-seated mud source layer requires a larger minimum overpressure to form mud volcanoes, favoring the formation of a mud diapir. In contrast, for a thin sediment sequence, small pressure will be required in the mud source layer giving rise to a mud volcano.

The multiphase mud diapir/volcanic activity presented on the seismic profile reflects the process of "releaseaccumulation-release" of energy (overpressure) in the source layer. During the upward movement of the piercing structure-forming fluid, the $P$ decreases and this leads to the cessation of intrusion activity. When energy accumulation reaches a high level and tectonic activity occurs, energy 


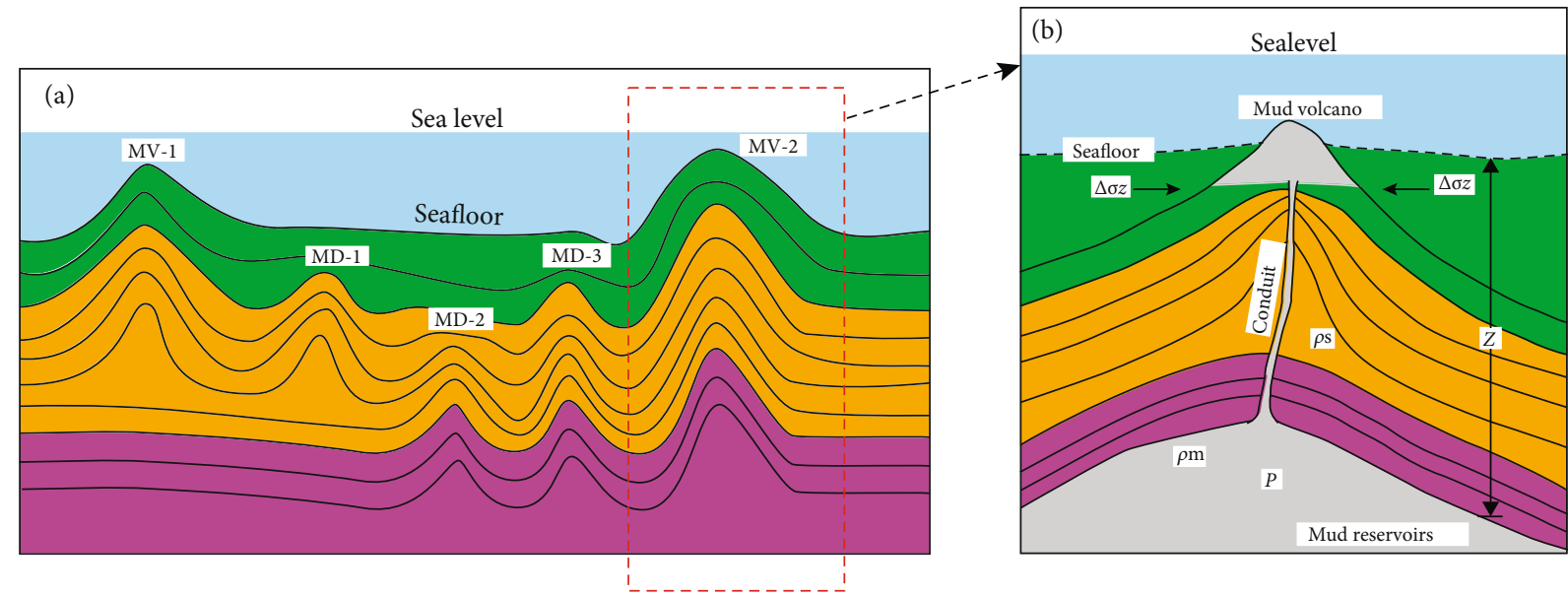

Figure 10: Pattern diagram of the formation mechanism of mud volcanoes and mud diapirs. (a) Stratigraphic profile of mud volcanoes and mud diapirs. MD-1, MD-2, and MD-3 are mud diapirs, which puncture through different layers, and the source layers of MD-1 are shallower than MD-2 and MD-3. MV-1 and MV-2 are mud volcanoes, and the source layers of MV-2 are deeper than MV-1. (b) Internal structure diagram of MV-2, $Z$ is the depth of the source, $\Delta \sigma$ is the tectonic stress, $P$ is the overpressure in mud reservoirs, and $\rho_{\mathrm{s}}$ and $\rho_{\mathrm{m}}$ are the densities of the surrounding rock and mud, respectively.

is released and the fluid starts rising again through a network of open fractures. When the mud source layer is under high $P$ conditions, the fluid can be transported up to the seabed to form a mud volcano. If not, mud diapir will be formed. Therefore, the existence of a thick Cenozoic sedimentary sequence in the Yinggehai Basin most likely permitted the formation of mud diapirs instead of mud volcanoes. In contrast, the relatively thin sedimentary sequence in the Southwest Taiwan Basin led to the genesis of mud volcanoes.

By the reasoning in the foregoing paragraphs, it is concluded that tectonic stress, the thickness of sediment, and regional faulting are factors that exert significant control over the type of the resultant piercing landform.

\section{Conclusions}

The fluid leakage structures cropping out on the seafloor of the sediment basins hosted in the northern continental margin of the South China Sea show significant variations in their morphological and structural characteristics. Differences in stress field do not directly lead to the difference in the scale of mud volcanoes or diapirs. Overpressure is not the only energy for the formation and evolution of mud diapirs/volcanoes; fractures may play an important role in this process. The thickness of the sediment has a strong impact on the formation of fluid leakage structures that thicker sediment is more conducive to the development of mud diapirs and the thinner one is more likely to form mud volcanoes.

\section{Data Availability}

The data used to support the findings of this study are available from the corresponding author upon request.

\section{Disclosure}

The findings achieved herein are solely the responsibility of the authors.

\section{Conflicts of Interest}

The authors declare that they have no conflicts of interest.

\section{Acknowledgments}

This work was supported by the Fund of National Key R\&D Program of China (No. 2018YFC0310000), the Southern Marine Science and Engineering Guangdong Laboratory (Zhanjiang, No. ZJW-2019-03-001), the National Nature Science Foundation of China (Nos. 41776056 and 42076054), the China Postdoctoral Science Foundation (No. 2020M672671), the China National Hydrate Project (Nos. DD20190217 and DD20190224), and the Natural Science Foundation of Guangdong Province (No. 2018B030311030).

\section{References}

[1] L. I. Dimitrov, "Mud volcanoes-the most important pathway for degassing deeply buried sediments," Earth Science Reviews, vol. 59, no. 1-4, pp. 49-76, 2002.

[2] A. V. Milkov, "Worldwide distribution of submarine mud volcanoes and associated gas hydrates," Marine Geology, vol. 167, no. 1-2, pp. 29-42, 2000.

[3] G. Etiope and A. V. Milkov, "A new estimate of global methane flux from onshore and shallow submarine mud volcanoes to the atmosphere," Environmental Geology, vol. 46, no. 8, pp. 997-1002, 2004.

[4] A. J. Kopf, "Making calderas from mud," Nature Geoscience, vol. 1, no. 8, pp. 500-501, 2008.

[5] A. J. Kopf, "Significance of mud volcanism," Reviews of Geophysics, vol. 40, no. 2, pp. 1-52, 2002. 
[6] D. Behain, Gas Hydrate Offshore NW Sabah: Morpho-Tectonic Influence on the Distribution of Gas Hydrate and Estimation of Concentration of Gas Hydrate above and Free Gas below the Gas Hydrate Stability Zone, Clausthal University of Technology, Clausthal-Zellerfeld, Germany, 2005.

[7] A. Judd and M. Hovland, Seabed Fluid Flow: The Impact on Geology, Biology and the Marine Environment, Cambridge University, 2007.

[8] Z. Wan, Q. Shi, F. Guo, Y. Zhong, and B. Xia, "Gases in southern Junggar Basin mud volcanoes: chemical composition, stable carbon isotopes, and gas origin," Journal of Natural Gas Science and Engineering, vol. 14, pp. 108-115, 2013.

[9] M. Bonini, M. L. Rudolph, and M. Manga, "Long- and shortterm triggering and modulation of mud volcano eruptions by earthquakes," Tectonophysics, vol. 672-673, pp. 190-211, 2016.

[10] U. Ujiie, "Mud diapirs observed in two piston cores from the landward slope of the northern Ryukyu Trench, northwestern Pacific Ocean," Marine Geology, vol. 163, no. 1-4, pp. 149-167, 2000.

[11] C. Huguen, J. Mascle, J. Woodside, T. Zitter, and J. P. Foucher, "Mud volcanoes and mud domes of the Central Mediterranean Ridge: near-bottom and in situ observations," Deep Sea Research Part I: Oceanographic Research Papers, vol. 52, no. 10, pp. 1911-1931, 2005.

[12] C. Lei, J. Ren, P. D. Clift, Z. Wang, X. Li, and C. Tong, “The structure and formation of diapirs in the Yinggehai-Song Hong Basin, South China Sea," Marine and Petroleum Geology, vol. 28, no. 5, pp. 980-991, 2011.

[13] Z. Wan, Y. Yao, K. Chen, S. Zhong, B. Xia, and Y. Sun, "Characterization of mud volcanoes in the northern Zhongjiannan Basin, western South China Sea," Geological Journal, vol. 54, no. 1, pp. 177-189, 2019.

[14] A. Camerlenghi, M. B. Cita, B. Della Vedova, N. Fusi, L. Mirabile, and G. Pellis, "Geophysical evidence of mud diapirism on the Mediterranean Ridge accretionary complex," Marine Geophysical Research, vol. 17, no. 2, pp. 115-141, 1995.

[15] A. F. Limonov, J. M. Woodside, M. B. Cita, and M. K. Ivanov, "The Mediterranean Ridge and related mud diapirism: a background," Marine Geology, vol. 132, no. 1-4, pp. 7-19, 1996.

[16] A. Kopf, A. H. F. Robertson, and N. Volkmann, "Origin of mud breccia from the Mediterranean Ridge accretionary complex based on evidence of the maturity of organic matter and related petrographic and regional tectonic evidence," Marine Geology, vol. 166, no. 1-4, pp. 65-82, 2000.

[17] R. H. Sumner and G. K. Westbrook, "Mud diapirism in front of the Barbados accretionary wedge: the influence of fracture zones and North America-South America plate motions," Marine and Petroleum Geology, vol. 18, no. 5, pp. 591-613, 2001.

[18] A. F. Limonov, T. C. E. van Weering, N. H. Kenyon, M. K. Ivanov, and L. B. Meisner, "Seabed morphology and gas venting in the Black Sea mudvolcano area: observations with the MAK-1 deep-tow sidescan sonar and bottom profiler," Marine Geology, vol. 137, no. 1-2, pp. 121-136, 1997.

[19] S. Krastel, V. Spiess, M. Ivanov et al., "Acoustic investigations of mud volcanoes in the Sorokin Trough, Black Sea," GeoMarine Letters, vol. 23, no. 3-4, pp. 230-238, 2003.

[20] F. Gamberi and M. Rovere, "Mud diapirs, mud volcanoes and fluid flow in the rear of the Calabrian arc orogenic wedge (southeastern Tyrrhenian Sea)," Basin Research, vol. 22, no. 4, pp. 452-464, 2010.
[21] F. Pérez-Belzuz, B. Alonso, and G. Ercilla, "History of mud diapirism and trigger mechanisms in the western Alboran Sea," Tectonophysics, vol. 282, no. 1-4, pp. 399-422, 1997.

[22] A. Sautkin, A. R. Talukder, M. C. Comas, J. I. Soto, and A. Alekseev, "Mud volcanoes in the Alboran Sea: evidence from micropaleontological and geophysical data," Marine Geology, vol. 195, no. 1-4, pp. 237-261, 2003.

[23] T. F. Yang, G.-H. Yeh, C.-C. Fu et al., "Composition and exhalation flux of gases from mud volcanoes in Taiwan," Environmental Geology, vol. 46, no. 8, pp. 1003-1011, 2004.

[24] G. Etiope, A. Feyzullayev, and C. L. Baciu, "Terrestrial methane seeps and mud volcanoes: a global perspective of gas origin," Marine and Petroleum Geology, vol. 26, no. 3, pp. 333344, 2009.

[25] J. He, Y. Zhu, S. Weng, and S. Cui, "Characters of north-west mud diapirs volcanoes in South China Sea and relationship between them and accumulation and migration of oil and gas," Earth Science-Journal of China University of Geosciences, vol. 32, no. 1, pp. 75-86, 2010.

[26] G. D. Ginsburg, V. L. I. Vanov, and V. A. Soloviev, "Natural gas hydrates of the World's Oceans. Oil and gas content of the World's Oceans," in Oil and gas content of the World's Oceans, pp. 141-158, PGO Sevmorgeologia, 1984.

[27] D. Chen, D. Feng, G. Chen, X. Chen, and L. M. Cathles, "Evolution of marine gas venting system and impact on gas hydrate crystallization," Acta Sedimentologica Sinica, vol. 23, no. 2, pp. 323-328, 2005.

[28] Z. Sha, G. Zhang, J. Liang, and H. Wang, "Mud volcano-one live evidence of the existence of gas hydrates," Research of Gological South China Sea, vol. 17, no. 1, pp. 48-56, 2005.

[29] A. V. Egorov and A. N. Rozhkov, "Formation of gas hydrate reservoirs in submarine mud volcanos," Fluid Dynamics, vol. 45, no. 5, pp. 769-778, 2010.

[30] P. Franek, J. Mienert, S. Buenz, and L. Géli, "Character of seismic motion at a location of a gas hydrate-bearing mud volcano on the SW Barents Sea margin," Journal of Geoghysical Research Solid Earth, vol. 119, no. 8, pp. 61596177, 2015.

[31] W. K. Link, "Significance of oil and gas seeps in world oil exploration,” AAPG Bulletin, vol. 36, no. 8, pp. 1505-1540, 1952.

[32] M. A. Abrams, "Significance of hydrocarbon seepage relative to petroleum generation and entrapment," Marine and Petroleum Geology, vol. 22, no. 4, pp. 457-477, 2005.

[33] M. Rovere, F. Gamberi, and A. Mercorella, "Venting and seepage systems associated with mud volcanoes and mud diapirs in the southern Tyrrhenian Sea," Marine Geology, vol. 347, pp. 153-171, 2014.

[34] A. J. Kopf, "Global methane emission through mud volcanoes and its past and present impact on earth climate," International Journal of Earth Science, vol. 94, no. 3, pp. 493-494, 2005.

[35] E. J. Sauter, S. I. Muyakshin, J.-L. Charlou et al., "Methane discharge from a deep-sea submarine mud volcano into the upper water column by gas hydrate-coated methane bubbles," Earth and Planetary Science Letters, vol. 243, no. 3-4, pp. 354-365, 2006.

[36] R. Mellors, D. Kilb, A. Aliyev, A. Gasanov, and G. Yetirmishli, "Correlations between earthquakes and large mud volcano eruptions," Journal of Geophysical Research: Solid Earth, vol. 112, no. B4, article B04304, 2007. 
[37] M. Manga, M. L. Rudolph, and M. Brumm, "Earthquake triggering of mud volcanoes," Marine and Petroleum Geology, vol. 26, no. 9, pp. 1785-1798, 2009.

[38] Z. Wan, Q. Shi, Q. Zhang, S. Cai, and B. Xia, "Characteristics and developmental mechanisms of mud volcanoes on the southern margin of the Junggar Basin, NW China," Geological Journal, vol. 50, no. 4, pp. 434-445, 2015.

[39] S.-C. Chen, S.-K. Hsu, Y. Wang et al., "Distribution and characters of the mud diapirs and mud volcanoes off southwest Taiwan," Journal of Asian Earth Sciences, vol. 92, pp. 201214, 2014.

[40] C.-H. Sun, S.-C. Chang, C.-L. Kuo, J.-C. Wu, P.-H. Shao, and J.-N. Oung, “Origins of Taiwan's mud volcanoes: evidence from geochemistry," Journal of Asian Earth Sciences, vol. 37, no. 2, pp. 105-116, 2010.

[41] Q. Sun, S. Wu, J. Cartwright, and D. Dong, "Shallow gas and focused fluid flow systems in the Pearl River Mouth Basin, northern South China Sea," Marine Geology, vol. 315-318, pp. 1-14, 2012.

[42] A. Zoporowski and S. A. Miller, "Modelling eruption cycles and decay of mud volcanoes," Marine and Petroleum Geology, vol. 26, no. 9, pp. 1879-1887, 2009.

[43] P. Yan, Y. Wang, J. Liu, G. Zhong, and X. Liu, "Discovery of the southwest Dongsha Island mud volcanoes amid the northern margin of the South China Sea," Marine and Petroleum Geology, vol. 88, pp. 858-870, 2017.

[44] M. Nuzzo, M. Elvert, M. Schmidt et al., "Impact of hot fluid advection on hydrocarbon gas production and seepage in mud volcano sediments of thick Cenozoic deltas," Earth and Planetary Science Letters, vol. 341-344, no. 8, pp. 139-157, 2012.

[45] J. Chen, H. Song, Y. Guan et al., "Morphologies, classification and genesis of pockmarks, mud volcanoes and associated fluid escape features in the northern Zhongjiannan Basin, South China Sea," Deep Sea Research Part II: Topical Studies in Oceanography, vol. 122, pp. 106-117, 2015.

[46] Z. Wan, X. Xu, X. Wang, B. Xia, and Y. Sun, "Geothermal analysis of boreholes in the Shenhu gas hydrate drilling area, northern South China Sea: influence of mud diapirs on hydrate occurrence," Journal of Petroleum Science and Engineering, vol. 158, 2017.

[47] W. Zhang, J. Liang, X. Yang, P. Su, and Z. Wan, "The formation mechanism of mud diapirs and gas chimneys and their relationship with natural gas hydrates: insights from the deep-water area of Qiongdongnan Basin, northern South China Sea," International Geology Review, vol. 62, no. 7-8, pp. 789-810, 2018.

[48] W. Zhang, J. Liang, P. Su et al., "Distribution and characteristics of mud diapirs, gas chimneys, and bottom simulating reflectors associated with hydrocarbon migration and gas hydrate accumulation in the Qiongdongnan basin, northern slope of the South China Sea," Geological Journal, vol. 54, no. 6, pp. 3556-3573, 2019.

[49] W. Zhang, Research on the Development and Evolution of Mud Diapir/Mud Volcano and their Relationship with Migration and Accumulation of Petroleum and Natural Gas-Hydrate in Major Basins, Northern South China Sea, Graduate University of Chinese Academy of Sciences (Guangzhou Institute of Geochemistry), 2016.

[50] C. Berndt, "Focused fluid flow in passive continental margins. Philosophical Transactions of the Royal Society A: Mathemat- ical," Physical and Engineering Sciences, vol. 363, no. 1837, pp. 2855-2871, 2005.

[51] M. Huuse, C. A. L. Jackson, P. Van Rensbergen, R. J. Davies, P. B. Flemings, and R. J. Dixon, "Subsurface sediment remobilization and fluid flow in sedimentary basins: an overview," Basin Research, vol. 22, no. 4, pp. 342-360, 2010.

[52] A. Gay, Y. Takano, W. P. Gilhooly III et al., "Geophysical and geochemical evidence of large scale fluid flow within shallow sediments in the eastern Gulf of Mexico, offshore Louisiana," Geofluids, vol. 11, no. 1, 47 pages, 2011.

[53] W. Hamilton, Tectonics of the Indonesian Region. Geological Survey Professional Paper, Government Printing Office, 1979.

[54] P. Tapponnier, G. Peltzer, A. Y. L. Dain, R. Armijo, and P. Cobbold, "Propagating extrusion tectonics in Asia: new insights from simple experiments with plasticine," Geology, vol. 10, no. 12, pp. 611-616, 1982.

[55] A. Briais, P. Patriat, and P. Tapponnier, "Updated interpretation of magnetic anomalies and seafloor spreading stages in the South China Sea: implications for the tertiary tectonics of southeast Asia," Journal of Geophysical Research, vol. 98, no. B4, pp. 6299-6328, 1993.

[56] J. Li, "Dynamics of the continental margins of South China Sea: scientific experiments and research progresses," Chinese Journal of Geophysics, vol. 54, no. 12, pp. 2993-3003, 2011.

[57] Y. Qiu, L. Wang, and W. Huang, Sedimentary Basins in Mesozoic and Cenozoic in the China Seas, Geological Publishing House, Beijing, China, 2016.

[58] S. Nissen, D. Hayes, B. Peter et al., "Deep penetration seismic soundings across the northern margin of the South China Sea," Journal of Geophysical Research: Solid Earth, vol. 100, no. B11, pp. 22407-22433, 1995.

[59] P. Clift, J. Lin, and U. Barckhausen, "Evidence of low flexural rigidity and low viscosity lower continental crust during continental break-up in the South China Sea," Marine and Petroleum Geology, vol. 19, no. 8, pp. 951-970, 2002.

[60] B. Xia, Y. Zhang, X. J. Cui et al., "Understanding of the geological and geodynamic controls on the formation of the South China Sea: a numerical modelling approach," Journal of Geodynamics, vol. 42, no. 1-3, pp. 63-84, 2006.

[61] Z. Sun, Z. Zhong, M. Keep et al., "3D analogue modeling of the South China Sea: a discussion on breakup pattern," Journal of Asian Earth Sciences, vol. 34, no. 4, pp. 544-556, 2009.

[62] W. Zhu, G. Zhang, and S. Yang, Natural gas geology in the southern southern part of the south China sea, Petroleum Industry Press, Beijing, China, 2007.

[63] J. Chen, Y. Guan, H. Song et al., "Distribution characteristics and geological implications of pockmarks and mud volcanoes in the northern and western continental margins of the South China Sea," Chinese Journal of Geophysics, vol. 58, no. 3, pp. 919-938, 2015.

[64] Z. Gong and S. Li, Dynamic Research of Oil and Gas Accumulation in Northern Margin Basins of South China Sea, Science Press, Beijing, China, 2004.

[65] W. Zhang, J. Liang, J. He, X. Cong, and P. Su, "Characteristics of mud diaper and gas chimney and their relationship with reservoir forming for petroleum and natural gas hydrate on northern slope of the South China Sea," Marine Geology Frontiers, vol. 33, no. 7, pp. 11-23, 2017.

[66] J. Wang, X. Pang, C. Wang, M. He, and S. Lian, "Discovery and recognition of the central diapiric zone in Baiyun depression, 
Pearl River Mouth Basin," Earth Science-Journal of China University of Geosciences, vol. 31, no. 2, pp. 209-313, 2006.

[67] P. Yan, Y. Wang, H. Zheng, D. Zou, and Z. Chen, "Geophysical features of mud volcanoes in the waters southwest of Dongsha Islands," Acta Oceanologica Sinica, vol. 36, no. 7, pp. 142-148, 2014.

[68] S. Chen, H. He, J. He et al., "The characters of the mud volcanoes in the north-east marginal of the South China Sea and the relationship with the accumulation and migration of oil and gas," Natural Gas Geoscience, vol. 20, no. 6, pp. 872-878, 2009.

[69] J.-K. Chiu, W.-H. Tseng, and C.-S. Liu, "Distribution of gassy sediments and mud volcanoes offshore southwestern Taiwan," Ocean, vol. 17, no. 4, pp. 703-722, 2006.

[70] S.-C. Sun and C.-S. Liu, "Mud diapir and submarine channel deposits in offshore Kaosiung-Hengchun, southwest Taiwan," Petroleum Geology of Taiwan, vol. 28, pp. 1-14, 1993.

[71] A. T. Lin, B. Yao, S.-K. Hsu, C.-S. Liu, and C.-Y. Huang, "Tectonic features of the incipient arc-continent collision zone of Taiwan: implications for seismicity," Tectonophysics, vol. 479, no. 1-2, pp. 28-42, 2009.

[72] M. Bonini, "Mud volcanoes: indicators of stress orientation and tectonic controls," Earth Science Reviews, vol. 115, no. 3, pp. 121-152, 2012.

[73] T. Zhu, X. Lu, Y. Zhu, and W. Hu, “A preliminary genetic study of the Wushanding mud volcano in southwestern Taiwan," Acta Petrologica et Mineralogica, vol. 28, no. 5, pp. 465-472, 2009.

[74] J. He, H. Liu, Y. Yao, S. Zhang, and X. Luan, Petroleum Geology and Resource Prospect of the Northern Marginal Basin of the South China Sea, Petroleum Industry Press, Beijing, China, 2008.

[75] Z. Wang, Z. Liu, Z. Wang et al., "Distribution characteristics of abnormal pressure in central depression belt, deepwater area, Qiongdongnan (Southeast Hainan) basin," Acta Geoscientica Sinica, vol. 35, no. 3, pp. 355-364, 2014.

[76] W. Shi, Z. Song, X. Wang, and M. Kong, "Diapir structure and its origin in the Baiyun depression, Pearl River Mouth Basin, China," Earth Science-Journal of China University of Geosciences, vol. 34, no. 5, pp. 778-784, 2009.

[77] Q. Sung, H. Chang, H. Liu, and Y. Chen, "Mud volcanoes along the Chishan fault in southwestern Taiwan: a release bend model," Geomorphology, vol. 118, no. 1-2, pp. 188-198, 2010.

[78] A. M. Pitt and R. A. Hutchinson, "Hydrothermal changes related to earthquake activity at mud volcano, Yellowstone National Park, Wyoming," Journal of Geophysical Research, vol. 87, no. B4, pp. 2762-2766, 1982.

[79] R. J. Davies, M. Brumm, M. Manga, R. Rubiandini, R. Swarbrick, and M. Tingay, "The East Java mud volcano (2006 to present): an earthquake or drilling trigger?," Earth and Planetary Science Letters, vol. 272, no. 3-4, pp. 627-638, 2008.

[80] T. Feseker, A. Boetius, F. Wenzhöfer et al., "Eruption of a deep-sea mud volcano triggers rapid sediment movement," Nature Communications, vol. 5, no. 1, p. 5385, 2014.

[81] C. Nostro, R. S. Stein, M. Cocco, M. E. Belardinelli, and W. Marzocchi, "Two-way coupling between Vesuvius eruptions and southern Apennine earthquakes, Italy, by elastic stress transfer," Journal of Geophysical Research: Solid Earth, vol. 103, no. B10, pp. 24487-24504, 1998.
[82] T. R. Walter, "How a tectonic earthquake may wake up volcanoes: stress transfer during the 1996 earthquake-eruption sequence at the Karymsky Volcanic Group, Kamchatka," Earth and Planetary Science Letters, vol. 264, no. 3-4, pp. 347-359, 2007.

[83] X. Cheng, Z. Chen, and W. Bai, "A numerical simulation of magma migration in crust fracture-an application to Changbaishan Tianchi volcano," Chinese Journal of Geophysics, vol. 57, no. 5, pp. 1522-1533, 2014. 